\title{
Explaining the Modernized Leasing and Right-of-Way Regulations for Indian Lands
}

\author{
Kevin Washburn \\ University of New Mexico - School of Law \\ Jody Cummings
}

Follow this and additional works at: https://digitalrepository.unm.edu/law_facultyscholarship

Part of the Indian and Aboriginal Law Commons

\section{Recommended Citation}

Kevin Washburn \& Jody Cummings, Explaining the Modernized Leasing and Right-of-Way Regulations for Indian Lands, White Paper (2017).

Available at: https://digitalrepository.unm.edu/law_facultyscholarship/550

This Working Paper is brought to you for free and open access by the UNM School of Law at UNM Digital Repository. It has been accepted for inclusion in Faculty Scholarship by an authorized administrator of UNM Digital Repository. For more information, please contact amywinter@unm.edu, Isloane@salud.unm.edu,

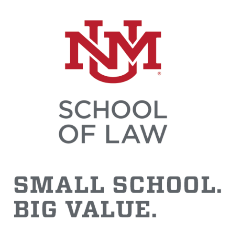

BIG VALUE. 


\title{
Explaining the Modernized Leasing and Right-of-Way Regulations for Indian Lands
}

\author{
Jody Cummings \\ Steptoe \& Johnson LLP \\ Kevin Washburn \\ Regents Professor \\ University of New Mexico School of Law ${ }^{1}$
}

Copyright $($ by Jody Cummings and Kevin Washburn. All rights reserved.

Abstract: The Obama Administration enacted significant reforms to the regulatory rules governing federal leasing and right of way approvals across tribal lands in Parts 162 and 169 of the Indian title of the federal regulations. These reforms had many aims. They sought to improve the environment for economic development on Indian reservations by speeding regulatory approvals, increasing predictability (by, in part, narrowing agency discretion), and increasing deference to tribal governmental decisions. The reforms sought to help tribal governments capture economic value that had previously been denied them, for example, by preventing socalled "piggybacking" on pre-existing rights of way and clarifying the rules of taxation related to economic activity. On the other hand, the reforms also sought to assure greater deference to tribal decisions, even when tribal governments act for non-economic purposes. For example, the agency will now defer to decisions to lease land for less than fair market value if a tribal government wishes for approval for other reasons. This descriptive work, prepared for a Rocky Mountain Mineral Law Foundation conference in 2017, details these regulatory reforms.

\section{Introduction}

One hallmark of the early 21st Century has been the expanding role of tribal governments in managing Indian land. ${ }^{2}$ Driven by robust tribal economic development that began in the 1970s and increasing disappointment with federal efforts to manage federal Indian lands, ${ }^{3}$ tribes have prioritized self-governance of Indian lands. In part because of this important tribal priority, federal decision-makers have shown increased deference to tribal sovereign authority to make decisions about tribal lands. Federal policy, however, has not always kept pace with the progress of tribal governments in Indian country.

\footnotetext{
${ }^{1}$ The authors wish to thank Elizabeth Appel, Kayla Danks, Matthew Kirkland, Del Laverdure, Bryan Newland, Larry Roberts, Sharlene Roundface, Stephen Simpson, Jennifer Turner, Stan Webb, and other U.S. Department of the Interior and Bureau of Indian Affairs officials who worked on the reforms discussed herein. This paper was originally published by the Rocky Mountain Mineral Law Foundation in the manual of the Special Institute on Advanced Indian Law and Natural Resources: The Basics and Beyond (2017).

${ }^{2}$ Consistent with the definitions found in 25 C.F.R. Parts 162 and 169 as described below, "Indian land" as discussed here generally refers to any tract of land that is held in trust by the United States for the benefit of a tribe or individual Indian, or restricted fee land that is owned by a tribe or individual Indian.

${ }^{3}$ See, e.g., Navajo Nation v. United States, 537 U.S. 488 (2003) (alleging wrongdoing by the federal trustee in its role in managing tribal mineral resources).
} 
In 2012 and 2015, respectively, the U.S. Department of the Interior (“Interior”) adopted new regulations dealing with leasing and rights-of-ways on Indian lands. Section I of this essay will provide a high-level overview of the purposes of the reforms. Section II will detail the specific changes created by the new rules. Section III will discuss areas of discord and litigation that is expected or has already occurred.

\section{Overview}

The stated purposes behind the new leasing and right-of-way regulations were modernization, flexibility, improved responsiveness, clarity of taxation, and general improvements in the regulatory process for federal approvals.

\section{Modernization and Flexibility}

One of the principal goals of the regulatory changes was to make each regime more consistent with modern norms of federal Indian policy. Neither regulatory structure had been amended significantly in decades. The original schemes had been developed at a time when the Bureau of Indian Affairs ("BIA") at Interior exercised the central authority on Indian reservations and tribal governments generally deferred to BIA decisions, a time when people jokingly said that "BIA" stood for "Bossing Indians Around."

In a number of ways over the past several decades, tribal governments have reassumed the status of principal governing authority on Indian reservations and the BIA has transitioned to an important supporting role. It is no longer controversial to suggest that tribal nations should be self-governing. Controversy sometimes arises, however, as this principle is implemented.

As tribal governmental leadership has focused increasingly on jobs and economic development, the ancient BIA processes had come to represent obstacles to effective economic development. The regulatory approval process for leases and rights-of-way had become a gauntlet of regulatory hurdles that slowed economic development and frustrated economic progress. Prior to the recent reforms, much of the focus of the regulatory gauntlet involved limiting federal liability for BIA decisions. For example, an appraisal was required for every lease or right-of-way decision even if the tribe or individual Indian owner was competent to make decisions and clearly desired approval. Tribal preference was irrelevant to that question.

In efforts to modernize these regimes and increase their transparency and efficiency, the regulations now build in greater flexibility for compensation and land valuations. Both sets of regulations give considerable deference to compensation terms negotiated by tribes in the place of requiring appraisals, and allow for alternative forms of payment, including in-kind consideration. The regulations also permit direct pay from lessees and grantees to landowners in certain circumstances, and give landowners significant leeway in determining how long a lease or right-of-way may last.

Interior also took steps, such as specifying separate, simplified processes for obtaining BIA approval of leases for residential, business, and wind and solar ("WSR") purposes on Indian land. The regulations also eliminate the requirement for BIA approval of permits for short term 
activities on Indian lands (in the case of leases) and create a distinct, less cumbersome process for utility service line agreements.

\section{Improved Responsiveness}

A widespread complaint about the BIA approval regime was that it was slow and cumbersome. Even a very simple lease, such as for a single home site, might languish for years in the approval process. Often, participants in the approval process would walk away in frustration before the culmination of the approval. In cases involving capital financing, rather than endure years of delay, investors in projects on Indian lands frequently were unwilling to wait on the regulatory process and chose instead to put their capital to work outside of Indian country.

To address this problem and provide swifter responses to applications for approval, Interior made several changes. The leasing regulations now impose strict deadlines requiring that the BIA issue decisions on completed residential lease applications within 30 days, and completed business and WSR applications within 60 days. For rights-of-way, the BIA now has 60 days to make a decision on a completed application (30 days for an amendment, assignment or mortgage of a right-of-way). To enforce these deadlines, the new regulations authorize appeals to higher-level BIA supervisors when a deciding official fails to make a timely decision.

\section{Taxation}

Taxation on Indian land subject to leases and rights-of-way has regularly been an area of significant confusion and dispute. State and local governments have often sought to impose taxes on permanent improvements and activities located on Indian land that is leased or subject to a right-of-way. These efforts have either hindered tribes from imposing their own taxes or subjected nonmember improvements and activities on leased land and within rights-of-way to threats of dual taxation, thereby potentially limiting economic development opportunities in tribal communities.

The leasing and right-of-way regulations now clarify that "subject only to applicable federal law," permanent improvements on leased land or within a right-of-way, activities conducted under a lease or right-of-way grant, and any leasehold or possessory interest or right-of-way interest is not subject to state or local taxes. Those improvements, activities, and interest, however, are subject to taxation by the Indian tribe with jurisdiction.

\section{Other Enhancements for Tribes and Tribal Members}

The revision of the leasing and right-of-way regulations provided Interior an opportunity to make other enhancements that further tribal sovereignty and protect Indian landowner interests. For example, with the intent of promoting tribal self-determination and self-governance, the right-ofway regulations address the U.S. Supreme Court's decision in Strate v. A-1 Contractors. ${ }^{4}$ In Strate, the Court treated a right-of-way for a state highway running through tribal land as the equivalent of alienated, non-Indian land, noting that the tribe had "expressly reserved no right to

${ }^{4} 520$ U.S. 438 (1997). 
exercise dominion or control over the right-of-way." 5 The revised Part 169 offers a Strate "fix" that requires a right-of-way grant to clarify that it does not diminish tribal jurisdiction or authority over nonmembers on Indian land. Both the leasing and right-of-way regulations also clarify that approved leases and rights-of-way on Indian land are subject to all applicable federal laws and all tribal laws (unless those tribal laws are inconsistent with applicable Federal law), but are generally not subject to state and local law.

The right-of-way regulations also benefit landowners by eliminating "piggybacking." For example, a right-of-way granted decades ago for a highway or sewer line cannot now be used for a fiber optic communications without further negotiations with tribal or individual landowners. The rules now clarify that the use of a right-of-way not within the scope of an existing grant is only authorized under a new or amended right-of-way grant. This change insures that a tribal or individual beneficiary of Indian land held in trust will obtain value for any use not contemplated under the original right-of-way.

Finally, in supporting job creation for tribal members, the regulations also authorize provisions in leases and rights-of-way that would require grantees to give employment preferences to tribal members. With these features of the new regulations highlighted, we turn now to a broader review of the updated regulations.

\section{Reviewing the Updated Regulations}

\section{Leasing Indian Lands - 25 C.F.R. Part 162}

For decades, Interior has maintained regulations governing surface leasing authorized by various federal statutes for tribal and individual Indian trust and restricted fee lands. In late 2012, Interior finalized significant revisions for the BIA Indian land leasing regulations (25 C.F.R. Part 162, Leases and Permits). With these changes, the BIA replaced a subpart of provisions generally covering "non-agricultural leases" with subparts aimed at specific land uses: residential leasing; business leasing; and wind resource evaluation/wind and solar resource leasing. ${ }^{6}$ As part of these changes, the BIA also revised Part 162's general provisions, providing direction on when nonagricultural leases are needed, how leases are obtained, and terms for lease administration. The BIA describes the Part 162 revisions as clarifying the procedures for obtaining BIA approval of residential, business, and wind and solar lease documents; establishing deadlines for the BIA to issue decisions on complete residential, business, and wind and solar lease applications; defining

\footnotetext{
${ }^{5} I d$. at 455 .

${ }^{6} 25$ C.F.R. Part 162 (2017). Following the 2012 revisions, Part 162 now includes eight subparts: (A) General Provisions; (B) Agricultural Leases; (C) Residential Leases; (D) Business Leases; (E) Wind and Solar Resource Leases; (F) Special Requirements for Certain Reservations; and (G) Records. The 2012 revisions did not change Subpart B (covering agricultural leases) nor Subpart F (covering special requirements for certain reservations). To ensure that the revisions to Subpart A, General Provisions did not impact the agricultural lease regulations, the pre2012 General Provisions section was moved to Subpart B, making those regulations applicable only to agricultural leases. See 77 Fed. Reg. 72440 (Dec. 5, 2012).
} 
what information and documents are necessary for a complete application; and providing greater deference to tribes for tribal land leasing decisions. ${ }^{7}$

\section{Relevant Statutory Authority}

A complication in Indian land leasing is that the authority to lease federal Indian lands has developed over time in several different statutes. Part 162 seeks to unify the process for lease approvals of "Indian land" 8 entered into under the authority of several statutes, including 25 U.S.C. $\S \S 380,415(a)$, and $4211,{ }^{9}$ as well as other tribe-specific statutes authorizing surface leases of Indian land with BIA approval. ${ }^{10}$ Some of the statutes were enacted for specific purposes.

Enacted in 1940, $\S 380$ authorizes the BIA to lease restricted allotments of deceased allottees in particular circumstances. ${ }^{11}$ Congress has provided broad leasing authority to the BIA in $\S 380$ for such allotments, with an exception only for "oil and gas mining purposes." 12

Section 415(a), which is part of the Indian Long Term Leasing Act of 1955, and perhaps the most widely-used authority for non-agricultural surface leasing, authorizes leasing of tribally and individually-owned Indian land, with BIA approval, "for public religious, educational, recreational, residential, or business purposes, including the development or utilization of natural resources in connection with operations under such leases, for grazing purposes, and for those farming purposes which require the making of a substantial investment in the improvement of

\footnotetext{
${ }^{7}$ See 77 Fed. Reg. at 72440.

${ }^{8}$ The term "Indian land" is defined by $§ 162.003$ to include "any tract in which any interest in the surface estate is owned by a tribe or individual Indian in trust or restricted status and includes both individually-owned Indian land and tribal land." That section defines "individually-owned Indian land" as "any tract, or interest therein, in which the surface estate is owned by an individual Indian in trust or restricted fee." Likewise, "tribal land" is "any tract, or interest therein, in which the surface estate is owned by one or more tribes in trust or restricted status, and includes such lands reserved for BIA administrative purposes. The term also includes the surface estate of lands held by the United States in trust for [a tribal corporation established under Section 17 of the Indian Reorganization Act of 1934].” Id. Although not the focus of this paper, Part 162 also covers the leasing of "Government land," defined by $\S 162.003$ as "any tract, or interest therein, in which the surface estate is owned and administered by the United States, not including Indian land.” Id.

${ }^{9}$ Beyond these general surface leasing statutes identified in $\S 162.006(a)$, Part 162 also governs BIA approval of surface leases authorized by Congress for specific tribes under conditions that may differ from 25 U.S.C. §§ 380, 415(a) or 4211. See, e.g., 25 U.S.C. § 415(c) (leases involving Hopi Tribe), (d) (leases of restricted lands for the Navajo Nation); $\S \S 416-416 j$ (leases of trust or restricted lands on San Xavier and Salt River Pima-Maricopa Indian Reservations).

10 See 25 C.F.R. § 162.006(a). Subsection 162.006(b) (2) explains that Part 162 does not apply to land use agreements entered under other authorities, such as agreements encumbering tribal land under 25 U.S.C. § 81 (25 C.F.R. Part 84), Indian trader licenses (25 C.F.R. Part 140), timber contracts (25 C.F.R. Part 163), grazing permits (25 C.F.R. Part 166), and mineral leases (25 C.F.R. Parts 211-213, 225-227), among others. See id. § 162.006(b)(1). Nor does Part 162 generally apply to water rights leasing. See id. § 162.006(b)(2).

11 See 25 U.S.C. $\S 380$ (authorizing leasing "(1) when the heirs or devisees of such decedents have not been determined and (2) when the heirs or devisees of the decedents have been determined, and such lands are not in use by any of the heirs and the heirs have not been able during a three-moths' period to agree upon a lease by reason of the number of the heirs, their absence from the reservation, or for other cause, under such rules and regulations as the Secretary of the Interior may prescribe.”)

${ }^{12} I d$.
} 
the land for the production of specialized crops as determined by [the BIA]." ${ }^{13}$ Section 415(a) generally authorizes leases for a term of up to 25 years, with the option for a renewal of up to 25 years. The statute also identifies more than 50 tribes for whom 99-year lease terms are authorized. ${ }^{14}$

Section 415(a) also includes considerations that might be addressed by zoning or land use laws in local or county jurisdictions. For example, it requires that prior to any lease approval, the BIA must ensure that "adequate consideration has been given to the use of the leased lands and the use of neighboring lands; the height, quality and safety of any structures or other facilities to be constructed on such lands; the availability of police and fire protection and other services; the availability of judicial forums for all criminal and civil causes arising on the leased lands; and the effect on the environment of the uses to which the leased lands will be subject." 15

An important related development occurred in July 2012, when Congress amended the Indian Long Term Leasing Act and President Obama signed into law the Helping Expedite and Advance Responsible Tribal Homeownership Act. ${ }^{16}$ Consistent with Interior's efforts to promote tribal self-determination and self-governance embodied by the changes to the Part 162 regulations, the HEARTH Act authorizes tribes to approve leases of their land for the purposes identified in section 415(a) (excluding any lease for exploration, development, or extraction of any mineral resources) without the need for Interior approval as long as the lease is executed under tribal regulations approved by Interior. The HEARTH Act authorizes tribes to approve business and agricultural leases of their lands for terms of 25 years, with options to renew for two additional 25-year terms, as well as leases for public, religious, educational, recreational, or residential purposes of up to 75 years. Further, the HEARTH Act requires Interior to approve tribal leasing regulations as long as the tribal regulations are consistent with Part 162 and provide for environmental review that meets Part 162's requirements. ${ }^{17}$ The HEARTH Act does not authorize tribes to approve leases of individually-owned Indian allotments. ${ }^{18}$

Section 4211 is the leasing provision included in the Native American Housing Assistance and Self-Determination Act of $1996 .{ }^{19}$ This section of NAHASDA authorizes the BIA to approve the leasing of trust and restricted lands owned by tribes and individual Indians for "housing development and residential purposes." ${ }^{20}$ It caps the term of any lease authorized by section 4211 at 50 years.

\footnotetext{
1325 U.S.C. § 415(a).

${ }^{14}$ See id.

${ }^{15} \mathrm{Id}$.

1625 U.S.C. § 415(h) (“HEARTH Act”).

${ }^{17}$ See id. According to Interior's HEARTH Act website, Interior has approved HEARTH Act regulations for 26 tribes. See HEARTH Act of 2012, https://www.bia.gov/WhoWeAre/BIA/OTS/HEARTH/index.htm. Most of the approved submissions are for business leasing regulations, although submissions for residential, agricultural, and WSR leasing have also been approved.

1825 U.S.C. § 415(h)(2).

19 See 25 U.S.C. §§ 4101-4243 ("NAHASDA”).

${ }^{20}$ Id. $\S 4211$.
} 


\section{Part 162's Revised Subparts}

\section{Subpart A}

Many of the broadest and most important provisions of the leasing updates are found in Subpart A, which sets forth Part 162's general provisions governing the non-agricultural leasing contemplated by the rule: residential leases (Subpart C); business leases (Subpart D); wind energy evaluation, wind resource, and solar resource leases (Subpart E); and leasing on specific reservations (Subpart F). Subpart A includes instructions on when leases are needed, how leases may be obtained, and terms for lease administration.

Interior approval for non-agricultural surface leasing is required under Part 162 for any person who does not own the Indian land to be leased. ${ }^{21}$ In theory, even Indian landowners who own an undivided fractional interest in the land to be leased must obtain a lease from the owners of the other trust and restricted interest in the land, unless all of those owners have given permission for possession of the land without a lease. In part to mitigate the burden of this requirement, the 2012 updates include a more informal process for short-term uses of the land. For example, Interior now excepts Indian land use "permits" from requiring agency approval. In doing so, Part 162 characterizes a permit as a temporary, revocable land use privilege that falls short of a possessory interest in land conveyed by a lease. ${ }^{22}$ While the BIA no longer administers or enforces permits on Indian land and instead, leaves those tasks to Indian land owners and permittees, Part 162 permits should nevertheless be submitted for agency review to confirm that an interest in Indian land is not being granted and that the parties need not enter a lease that would be subject to BIA approval. ${ }^{23}$

The leasing process is initiated by prospective lessees negotiating directly with tribal and individual Indian landowners. ${ }^{24}$ Tribes, adult Indian landowners, and emancipated minors may consent to a lease of their land. ${ }^{25}$ For fractionated land (i.e., a tract of land that is owned in common by multiple Indian landowners holding undivided interests in the land), unanimous consent is frequently very difficult or impossible to obtain. Unanimity is not now required.

\footnotetext{
${ }^{21}$ See 25 C.F.R. § 162.005.

22 See id. $\S 162.007$. "Permit” is defined as “a written, non-assignable agreement between Indian landowners or BIA and the permittee, whereby the permittee is granted a temporary, revocable privilege to use Indian land or Government land, for a specified purpose.” Id. $\S 162.003$. Section 162.007 generally characterizes permits as not granting a legal interest in Indian land, subject to a shorter term, providing for limited use with a non-possessory right of access for the permittee and subject to termination to by the Indian landowner at any time.

${ }^{23}$ Id.

24 See id. § 162.010 .

25 See id. § 162.013(a). Likewise, consent to a lease may be provided on behalf of landowners who lack legal capacity consent to do so directly by: (1) an adult with legal custody acting on behalf of a minor child; (2) a fiduciary appointed by a court with jurisdiction on behalf on an individual Indian landowner; (3) a person authorized to appear before the Department of the Interior under 43 C.F.R. $\S 1.3(\mathrm{~b})$ who has been retained by an Indian landowner to provide consent; (4) the BIA, in the event the conditions of $\S 162.013$ (c) are met; and (5) a person with a qualifying written power of attorney. See 25 C.F.R. § 162.013(b).
} 
Instead, the regulations implement a sliding scale threshold for the percentage of undivided trust or restricted interests in the tract that must consent before the BIA will approve the lease. ${ }^{26}$

When the applicable consent threshold has been reached, the lease document will bind nonconsenting fractionated interest owners as if they had consented. ${ }^{27}$ The rule change further explains that such a lease will not bind any non-consenting tribe, except with respect to its tribally-owned fractional interest, and that the tribe will not be treated as a party to the lease. ${ }^{28}$

Subpart A introduces new provisions relating to applicable law and taxation for any leases that are approved by the BIA under Part 162. The rule makes three baseline announcements about what law applies to approved leases: (1) applicable federal law, including specific federal statutory requirements not already incorporated in Part 162, applies; (2) subject to some exceptions, tribal law applies; and (3) subject to some exceptions, state and local law do not apply. ${ }^{29}$

One of the continuing fundamental purposes of maintaining tribal trust land is to preserve a place where tribes are free to govern themselves and enjoy sanctuary from state laws. For state or local law, the regulations provide that either may apply in specific areas and circumstances if the Indian tribe with jurisdiction has made it expressly applicable. State law may also apply where Congress or a federal court has made it expressly applicable. ${ }^{30}$

Consistent with the general approach in Part 162's revisions of promoting tribal selfdetermination and self-governance, the regulations provide that if tribal law conflicts with Part 162 or other applicable federal law, a tribe may supersede or modify the regulations as long as it informs the BIA that tribal law will supersede the regulations, the superseding of the regulations will not violate federal law or conflict with the United States' general trust responsibility to tribes, and the superseding action will apply only to tribal land. ${ }^{31}$ In further support of tribal selfdetermination and landowner preference, the regulations permit leases to be subject to state or local law in the absence of Federal or tribal law as long as the Indian landowners expressly agree to such terms. ${ }^{32}$ Moreover, unless federal law requires otherwise, the regulations mandate that the BIA comply with tribal laws in making decisions relating to leases, including tribal laws

\footnotetext{
${ }^{26} I d$. § 162.012(a) (1). For tracts with one to five owners, the owners at least 90 percent of the fractionated interests must approve; for six to 10 owners, at least 80 percent; for 11 to 19 owners, at least 60 percent; for 20 or more owners, over 50 percent. These consent requirements are consistent with the Indian Long Term Leasing Act and the Indian Land Consolidation Act of 2000, as amended by the American Indian Probate Reform Act. See 77 Fed. Reg. at 72441. Leases in Alaska, however, require the consent of all Indian landowners in the tract given that ILCA does not apply in Alaska. Id.

${ }^{27}$ See 25 C.F.R. § 162.012(a) (4).

${ }^{28}$ See id. This provision also explains that nothing about its treatment of a non-consenting tribe or its fractionated interests that may be subject to a lease is intended to affect the tribe's sovereignty or sovereign immunity.

${ }^{29}$ See id. § 162.014.

${ }^{30}$ See id. § 162.014(a) (3).

${ }^{31}$ See id. § 162.014(b).

32 See id. § 162.014(c).
} 
regulating activities on leased land under tribal jurisdiction, such as tribal laws relating to land use, environmental protection and historic or cultural preservation. ${ }^{33}$

As to taxation, Subpart A states that subject only to applicable federal law, neither permanent improvements on leased land, activities under a lease conducted on lease land, nor a leasehold or possessory interest are to be subject to state or local taxation. ${ }^{34}$ The regulations recognize, however, that that such improvements, activities and interests on leased Indian land may be subject to taxation by a tribal government with jurisdiction over the land. ${ }^{35}$

The inapplicability of state and local taxes for tribes and their members who may be leasing Indian land for residential, business or wind and solar resource uses as contemplated by Part 162 is, of course, well settled. ${ }^{36}$ As for nonmember property and activities, the regulatory preamble to Part 162 makes the case for preemption of state taxation consistent with the U.S. Supreme Court's decision in White Mountain Apache Tribe v. Bracker, ${ }^{37}$ which directs courts to apply a balancing test to determine whether state taxation should be preempted. ${ }^{38}$ To acknowledge Bracker, each of $\S 162.017$ 's subsections included the phrase "subject only to applicable Federal law" to recognize that preemption must ultimately be determined on a case-by-case basis under Bracker. ${ }^{39}$ Section 162.017 reflects the official view of the federal Executive Branch that there is a strong federal interest in preemption of state taxation. Preemption furthers a very important federal interest in fostering tribal economic development and self-sufficiency. In support of state and local tax preemption, the Part 162 preamble argues: "[t]he Federal statutes and regulations governing leasing on Indian lands (as well as related statutes and regulations concerning business activities, including leases, by Indian traders) occupy and preempt the field of Indian leasing. The Federal statutory scheme for Indian leasing is comprehensive, and accordingly, precludes

\footnotetext{
${ }^{33}$ See id. § 162.016.

${ }^{34}$ See id. §§ 162.017(a) - (c). Although not addressing the question of whether Part 162 preempts state or local taxation of permanent improvements located on leased Indian land, the Ninth Circuit has recognized the principle acknowledged in \$162.017(a) that permanent improvements on such lands, regardless of ownership of the improvements, are not subject to state or local tax. See Confederated Tribes of the Chehalis Reservations v. Thurston Cty. Bd. Of Equalization, 724 F.3d 1153 (9 $9^{\text {th }}$ Cir. 2013) (“Chehalis”).

${ }^{35}$ See 25 C.F.R. § 162.017(a).

${ }^{36}$ See Cohen’s Handbook of Federal Indian Law § 8.03[1][b] (2012) (citing Okla. Tax Comm’n v. Chickasaw Nation, 515 U.S. 450, 458 (1995) ("when a state attempts to levy a tax directly on an Indian tribe or its members inside Indian country, rather than on non-Indians, we have employed . . ' 'a more categorical approach: . . . a State is without power to tax reservation lands and reservation Indians"” and noting that "[t]ribes and tribal members within Indian country have thus been found to be immune from a variety of state taxes, including excise taxes on motor fuels, motor vehicle excise taxes and registration fees, net income taxes, personal property taxes real property taxes on restricted land, cigarette excise taxes, vendor's license fees, and hunting and fishing licenses." (citations omitted)).

${ }^{37} 448$ U.S. 136 (1980).

3877 Fed. Reg. at 72447-72448 ("The Bracker balancing test requires a particularized examination of the relevant State, Federal, and tribal interests. . . . The Federal statutes and regulations governing leasing on Indian lands (as well as related statutes and regulations concerning business activities, including leases, by Indian traders) occupy and preempt the field of Indian leasing. The Federal statutory scheme for Indian leasing is comprehensive, and accordingly precludes State taxation. In addition, the Federal regulatory scheme is pervasive and leaves no room for State law.”).

${ }^{39}$ See Chehalis, 724 F.3d at 1158-1159.
} 
State taxation. In addition, the Federal regulatory scheme is pervasive and leaves no room for State law." 40 But even in taking this position in the regulatory preamble, Interior has encouraged tribal, state, and local governments to find workarounds for cooperative agreements when concerns arise about applicable tax law. ${ }^{41}$

Another highlight among the revised Subpart A's lease administration provisions is section 162.015, which recognizes that leases may include a provision requiring a lessee to give an employment preference to qualified tribal members. ${ }^{42}$ Other provisions in this portion of Subpart A provide guidance concerning when tribes may administer certain provisions of Part 162 on behalf of the BIA, for example, under 638 contracts or self-governance compacts; whether leases can address access to leased premises by roads or other infrastructure; combining tracts with different Indian landowners under one lease; the BIA's responsibilities in approving, administering and enforcing leases; use of Indian land without authorization; the BIA's authority to take emergency action on Indian land; appealing decisions made under Part 162; required documentation for lease-related actions; and providing notice to the parties to a lease. ${ }^{43}$ Notable here is language describing the BIA's role as Indian advocate during lease approval, responsible for assisting landowners in leasing their lands, promoting tribal control and self-determination over land under tribal jurisdiction, promptly responding to requests for BIA approval, and working to ensure that the use of the land is consistent with Indian landowners' wishes and applicable tribal law. ${ }^{44}$ Finally, in acknowledging the BIA's responsibility for lease administration and enforcement, and authority when unauthorized land use or emergency circumstances arise, the regulations also empower Indian landowners in those situations to exercise remedies available to them under a lease or applicable law. ${ }^{45}$

\section{Subparts C, D, and E}

In the regulatory process, the BIA received significant input about the different needs and considerations for different kinds of leases. As a result, other significant Part 162 revisions are found in the deletion of Subpart F (Non-agricultural Leases) and addition of three activityspecific subparts: Subpart C (Residential Leases), Subpart D (Business Leases), and Subpart E (Wind Energy Evaluation Leases ("WEELs") and Wind and Solar Resource ("WSR”) Leases). Key provisions in these three subparts are reviewed together here as significant overlap exists in how the BIA reviews and administers its responsibilities for such leases.

\footnotetext{
4077 Fed. Reg. at 72447 (In making its case for state tax preemption, Interior noted the breadth of Part 162's coverage of leasing of Indian lands. It also argued that the purposes of residential, business, and WSR leasing on Indian land are to promote Indian housing and to allow Indian landowners to use their land for economic development that ultimately supports tribal well-being and self-government. Assessing state and local taxes threatens these goals and hinders tribal government, economic self-sufficiency, and territorial autonomy.).

${ }^{41}$ See id. at 72448.

42 See 25 C.F.R. § 162.015.

${ }^{43}$ See id. §§ 162.018-029.

${ }^{44}$ See id. § 162.021.

${ }^{45}$ See id. §§ 162.022-024.
} 
Subpart C covers ground leases (undeveloped land) and leases of developed land (along with permanent improvements located there) for housing purposes. Leases approved under Subpart C can authorize construction or use of single-family residences or multi-unit public housing projects (including office space to administer such housing) on Indian land. ${ }^{46}$

Subpart D covers leases for undeveloped and developed land (together with any existing improvements located there) for a broad range of commercial, industrial, and other business purposes. Subpart D also acts as a catch-all subpart for residential leases that are not contemplated by Subpart C, business leases that are not the WEEL and WSL activities in Subpart $\mathrm{E}$, as well as leases that are needed for religious, educational, recreational and other public purposes. $^{47}$

Subpart E was designed to improve tribal opportunities to participate in the developing markets for renewable energy. It covers WEELs, which are short-term leases of Indian land to install, operate and maintain equipment and infrastructure to evaluate wind resources for electricity generation; and WSR leases, which are leases of Indian land to install, operate, and maintain equipment, facilities and other infrastructure (e.g., wind turbine and solar panels) for harnessing wind and/or solar energy to generate and supply electricity. ${ }^{48}$

Residential leases under the Long Term Leasing Act or NAHASDA, may extend for up to 50 years, which includes the time available for a renewal. ${ }^{49}$ Business and WSR leases may last as long 50 years if approved under the Indian Long Term Leasing Act (an initial 25-year maximum term with a maximum renewal term of 25 years) or even longer under other federal statutory authority. ${ }^{50}$ WEELs, by contrast, may be no longer than three years, but may include an option for a three-year renewal. ${ }^{51}$ When evaluating a proposed lease term, the revised regulations now require that the BIA defer to the leasing tribe's determination that the lease term is reasonable. ${ }^{52}$ For individually-owned land, the BIA will determine the reasonableness of the lease term given the purpose of the lease, type of financing, and level of investment. ${ }^{53}$

The regulations require that all leases covered by Subparts C-E include a set of basic lease details, ${ }^{54}$ as well as conditions by which the lessee will abide, including that: the obligations of a lessee and its sureties are also enforceable by the United States (as long as the land remains in trust or restricted status); there will be no unlawful or illegal activity, or negligent use or waste of

\footnotetext{
46 See id. § 162.301. "Housing for public purposes" is defined as "multi-family developments, single-family residential developments, and single-family residences: (1) Administered by a tribe of tribally designated housing entity (TDHE); or (2) Substantially financed using a tribal, Federal, or State housing assistance program or TDHE.” ${ }^{47}$ See id. § 162.401(a).

${ }^{48}$ See id. § 162.501.

49 See id. § 162.311.

50 The federal statute pursuant to which the lease is issued will dictate how long the lease may last. For example, 25 U.S.C. § 415(a) provides that for certain tribes, leases may have a maximum term of 99 years.

${ }^{51}$ See 25 C.F.R. $\S 162.512$.

${ }^{52}$ See id. § 162.311.

53 See id.

54 See id. §§ 162.313(a), 413(a), 513(a), 542(a) (lease must describe the land, lease purpose, authorized uses, time length, parties, ownership of and responsibility for permanent improvements, payment requirements).
} 
the leased premises; the lessee will comply will all applicable legal requirements; the lessee will contact the BIA and the tribe with jurisdiction over the land regarding certain events, and cease any activity occurring in the immediate vicinity of previously undiscovered cultural items, human remains or other archaeological resources; the BIA may enter the leased land for inspection and to ensure compliance; and the BIA may treat as a lease violation any failure by the lessee to cooperate with a BIA request to make relevant information available for BIA inspection. ${ }^{55}$ Unless prohibited by law, leases must also include a broad indemnification clause that protects the United States and the Indian landowners relating to the use or release of hazardous material from the leased premises. ${ }^{56}$

Business and WSR leases, and WEELs must include due diligence provisions imposing deadlines on the lessee to fulfill promises for construction of improvements and facilities within a specified time-frame and to ensure that equipment used for lease-related activities remains in working order. ${ }^{57}$ Business and WSR leases must also include an insurance provision to protect the interests of Indian landowners and insurable permanent improvements on the leased premises. Likewise, bonding provisions must be included in business and WSR leases to secure obligations under the lease such as construction or installation of improvements, and restoration and reclamation of the leased premises. ${ }^{58}$ At a landowner's request, the BIA may waive the insurance and bonding requirements upon determining that a waiver is in the landowner's best interest. Consistent with the broader purpose of supporting trial sovereignty and economic development, in making the waiver determination for tribal land, the revised regulations require that the BIA defer to the tribe's determination "to the maximum extent possible" about what may be in the tribe's best interest. ${ }^{59}$

Lease compensation is another area of significant revision. Generally, the regulations require any Indian land lease to pay at least fair market value. However, the BIA will defer to any payment amount negotiated by a tribe and not require a valuation for a lease if the tribe waives a valuation in writing and indicates that the agreed-upon amount is in the tribe's best interest. ${ }^{60}$ This flexibility reflects that a tribal government, for example, like state and local governments, may have a responsibility to its constituents that is not reflected by profit maximization, such as a need to use land for public housing. Even if the BIA provides a fair market rental value appraisal

\footnotetext{
55 See id. §§ 162.313(c), 413(c), 513(c), 542(c).

56 See id. §§ 162.313(d), 413(d), 513(d), 542(d) (no indemnification is required for liability arising from an Indian landowners’ negligence or willful misconduct).

57 See id. §§ 162.417, 517, 546.

${ }^{58}$ See id. $\S \S 162.434,559$

${ }^{59} \mathrm{Id}$ § 162.559.

60 See id. §§ 162.320(a), 420(a), 549(a). For residential leases, the BIA may alternatively defer to the tribe's negotiated lease amount and not require a valuation if the lease is for housing for public purposes. See id. $\S$ 162.320(a). The BIA will likewise defer to tribal decision making on accepting non-monetary and varying types of consideration, including in-kind consideration and payments based on percentage of income. See id. $\S \S 162.326(\mathrm{~b})$, 426(b), 555(b). Unlike residential, business, and WSR leases, the WEELs provisions do not mandate certain levels of rental compensation. However, because the WEELs incorporate by reference a subset of the WSR lease regulations relating to compensation, see id. $\S 162.523(\mathrm{~d})$, some compensation review issues may arise if circumstances are triggered that arise in $\S \S 162.552-558$.
} 
upon a tribal request, the BIA will nevertheless defer to the payment term negotiated by the tribe if these conditions are met. ${ }^{61}$ If neither of these circumstances occur, however, the BIA will require that a lease for tribal land provide for fair market rental based on a valuation consistent with the regulations. ${ }^{62}$

For individually-owned Indian land, the fair market value presumption is not required for residential leases if all individual landowners waive (in writing) the fair market value requirement or BIA waives the requirement. ${ }^{63}$ For business and WSR leases, payment of nominal or less than fair market value compensation may be approved as long as the individual landowners provide a written waiver of the right to receive fair market value and the BIA determines that an amount less than fair market value is in the landowners' best interest. ${ }^{64}$

Periodic review of leases to assess compensation adequacy follows a similar pattern. For tribal lands, periodic review or adjustment is not required if the tribe certifies that a waiver of reviews and/or adjustments is in its best interest. ${ }^{65}$ For individually-owned land, compensation adequacy review and adjustment is not required only if the lease term is less than five years, the lease provides for automatic adjustment, or the BIA determines that it is in the best interest of the Indian landowners not to require review or adjustment. ${ }^{66}$ When these circumstances do not exist, compensation adequacy review for tribal and individually-owned lands must occur under requirements specified in the lease. ${ }^{67}$ When compensation adjustment is necessary, Indian landowner consent is subject to the same percentage thresholds established for lease approval. ${ }^{68}$

The revised regulations also provide increased flexibility in how lease payments are made, including the form of payment that is required. Direct payment to Indian landowners is now authorized under the regulations as long as there are ten or fewer landowners for a given lease and all agree to receive payment directly from the lessee. ${ }^{69}$ Further, leases may provide for

61 See id. $\S \S 162.320(\mathrm{~b}), 420(\mathrm{~b})$, 549(b). For fair market value determinations, the BIA will use or approve a valuation method only if has been prepared in accordance with Uniform Standards of Professional Appraisal Practice or a valuation method developed by DOI under 25 U.S.C. § 2214. Further the method used must comply with DOI appraisal policies. See, e.g., 25 C.F.R. $\S \S 162.422(a)$ - (c). For business and WSR leases, Indian landowners may use competitive bidding as a valuation method. See id. § 162.422(d).

62 See id. §§ 162.320(c), 420(c), 549(c).

63 See id. § 162.321(b).

${ }^{64}$ See id. §§ 162.421(b), 550(b). In making that determination, several factors are considered, including whether the lessee is an immediate family member of an Indian landowner; the lessee is a co-owner of the tract; other special circumstances exist warranting approval; the lease is for public purposes; or if the BIA waives the requirement. See id. Also, non-monetary or varying types of compensation may be available for individually-owned land if the BIA determines it to be in the best interest of the Indian landowners. See id. §§ 162.326(c), 426(c), 555(c).

65 See id. §§ 162.328(a), 428(a), 557(a). For residential leases of tribal lands, periodic review and/or adjustment is also not required when the lease is for housing for public purposes. See id. $\S 162.328(\mathrm{a})(2)$.

66 See id. §§ 162.328(b), 428(b), 557(b). For residential leases of individual Indian lands, periodic review and/or adjustment is also not required when the lease is for housing for public purposes. See id. § 162.328(b)(1).

${ }^{67}$ See id. $\S \S 162.328(c), 428(c), 557(c)$.

${ }^{68}$ See id. $\S \S 162.328(d), 428(d), 557(d)$ (citing the general lease consent requirements of $\S 162.012$ ).

${ }^{69}$ See id. §§ 162.324(b), 424(b), 553(b). 
alternative forms of compensation agreed upon by the lease parties, including in-kind consideration and payments based on percentage of income. ${ }^{70}$

BIA lease approval requires a determination that the lease is in the best interest of the Indian landowner. With the 2012 revisions, the Part 162 regulations now work from a presumption that a lease agreed upon by an Indian landowner and a lessee in only a handful of circumstances will result in the BIA disapproving a lease sought under Subparts C-E: required consents under the sliding scale formula of $\S 162.012$ have not been obtained; the requirements of the applicable subpart have not been met; or the BIA finds a "compelling reason" to withhold approval in order to protect the best interest of the Indian landowner. ${ }^{71}$ Further, the regulations require that the BIA not unreasonably withhold lease approval, and that to the maximum extent possible, the BIA will defer to the Indian landowners' (whether tribe or individual) determination that the lease is in their best interest. ${ }^{72}$ Before issuing an approval, the BIA will (1) review the lease and supporting documents required by the regulations; (2) consider potential environmental impacts and ensure compliance with all applicable environmental laws, land use laws, and ordinances; (3) ensure that adequate review has been given to the factors specified in § 415(a) (if that is the authority for the lease) ${ }^{73}$ (4) and require any necessary lease modifications or mitigation measures necessary to satisfy Federal or tribal land use requirements, or other requirements. ${ }^{74}$

In another significant revision to Part 162, the regulations now impose deadlines on the BIA to act once a completed lease application is received. Residential lease applications are subject to 30 day deadlines, while business and WSR applications have 60 day deadlines, and WEELs have 20 day deadlines. ${ }^{75}$ Further, if the BIA fails to meet the required deadline, the revised regulations now make available a process to compel a decision through appeals to a BIA Regional Director, the BIA Director, and ultimately the Interior Board of Indian Appeals. ${ }^{76}$

The approval criteria for lease amendments, assignments, subleases and mortgages under Subparts C, D, and E are similar to new lease approvals. Generally, landowner consent is required at or above the same thresholds ${ }^{77}$ provided in $\S 162.012$ for consenting to a new lease. ${ }^{78}$

\footnotetext{
70 See id. $\S \S 162.326,426,555$.

${ }^{71}$ See id. §§ 162.341(a), 441(a), 531(a), 566(a).

72 See id. §§ 162.341(b)-(c), 441(b)-(c), 531(b)-(c), 566(b)-(c).

73 See 25 U.S.C. § 415(a) requires that “[p]rior to approval of any lease or extension of an existing lease pursuant to this section, the Secretary of the Interior shall first satisfy himself that adequate consideration has been given to the relationship between the use of the leased lands and the use of neighboring lands; the height, quality, and safety of any structures or other facilities to be constructed on such lands; the availability of police and fire protection and other services; the availability of judicial forums for all criminal and civil causes arising on the leased lands; and the effect on the environment of the uses to which the leased lands will be subject."

${ }^{74}$ See 25 C.F.R. $\S \S 162.340(\mathrm{a})$, 440(a), 530(a), 565(a).

75 See id. §§ 162.340(b)(2), 440(b)(2), 530(b)(2), 565(b)(2).

76 See id. $\S \S 162.340(\mathrm{c}), 440(\mathrm{c}), 530(\mathrm{c}), 565(\mathrm{c})$. Once the BIA has issued a decision on a lease application, the parties' appeal rights are governed by 25 C.F.R. Part 2.

77 Parties can, however, work around the BIA and landowner consent requirements in some circumstances for assignments and subleases. See, e.g., 25 C.F.R. § 162.349(b) (consent and BIA approval not necessary for residential lease assignment if lease is for housing for public purposes, or the assignee is a leasehold mortgagee or its designee, acquiring the lease by foreclosure or conveyance; the assignee agrees to assume all lease conditions; and assignee
} 
Similar to the presumption favoring lease approval, any proposed lease amendments, assignments, subleases and mortgages will be disapproved by the BIA only if certain conditions are met, such as when landowners have not consented (where consent is required); the lessee's mortgagees have not consented; the requirements of the applicable subpart of Part 162 have not been met; the lessee is in violation of the lease; the lessee would not remain liable under the lease (in the case of a sublease); the assignee does not agree to be bound by the terms of the lease (in the case of an assignment); or the BIA otherwise finds "compelling reason" to withhold approval to protect the Indian landowners' best interest. ${ }^{79}$ As with new lease approval, the BIA cannot unreasonably withhold its approval for a proposed amendment, assignment, sublease or mortgage, and will defer, to the maximum extent possible, to the Indian landowners' determination that such proposals are in their best interest.

Interior ends each of Subparts C, D, and E with a group of similar provisions on lease effectiveness, compliance and enforcement. These sections include guidance that govern timing for when amendments, assignments, subleases, and mortgages become effective; how parties may appeal disapprovals of amendments, assignments, subleases, and mortgages; and remedies for when the BIA fails to meet decision-making deadlines set forth in the regulations. ${ }^{80}$ They also cover conditions for how the BIA can determine and ensure lessee compliance with lease terms. ${ }^{81}$ Notably, these provisions include guidance on how lease violations are resolved, including the lease parties' ability to negotiate their own remedies for violations. The relevant sections make familiar distinctions between tribal and individually-owned Indian land found elsewhere in the rule. For tribal land, a lease may provide both parties with negotiated remedies

agrees that any transfer will be subject to applicable law under $\S 162.014$ ); $§ 162.453(b)$ (sublease of business lease does not have to meet consent or BIA approval requirements if the lease expressly says so; sublease does not relieve the lessee/sublessor of liability; and the parties give the BIA a copy of the sublease within 30 days of execution).

${ }^{78}$ Any attempt to amend, assign, sublease or mortgage a lease typically requires notification to all Indian landowners of the land at issue unless the lease provides otherwise. See, e.g., §§ 162.346(a), 450(a), 583(a). Beyond these special circumstances in which landowner consent requirements can be avoided for assignments and subleases, landowner consent for amendments, assignments, subleases, and mortgages is likewise unnecessary when: the lease provides for deemed consent by individual Indian landowners where they do not object in writing within a specified period of time following receipt of the proposed amendment, assignment, sublease or mortgage and the lease parties meet the BIA's deemed consent requirements; the lease authorizes one or more representatives to consent on behalf of all Indian landowners; or the lease designates the BIA as the Indian landowners' representative for the purpose of providing consent. See, e.g., id. §§ 162.346(b), .454(b), .579(b). Further, landowner consent for a mortgage is not necessary if the lease indicates as much and identifies what law would apply in the case of foreclosure. See, e.g., $\S$ 162.358(b) (1).

${ }^{79}$ These conditions vary slightly from subpart to subpart. See, e.g., 25 C.F.R. §§ 162.348(a), 456(a), 585. In finding a compelling reason to withhold approval, the BIA may consider various factors. Generally, the BIA may consider whether any value of the lease premises not covered by the amendment, assignment, sublease or mortgage will be adversely affected. See, e.g., id. § 162.456(b). Examples of other factors might include, for example, in the case of a residential leasehold mortgage, whether the mortgage proceeds would be used for purposes unrelated to the leased premises or whether the mortgage is limited to the leasehold. See id. § 162.360(b). Or in a WSR lease assignment, if a performance bond is required, the BIA will consider whether the assignee has posted the bond and provided supporting documents demonstrating that the lease will be enforceable against the assignee and that the assignee will be able to perform its obligations under the lease. See id. $\S 162.577(b)$.

${ }^{80}$ See id. §§162.361-363, 461-.463, 586-588.

${ }^{81}$ See id. §§ 162.364, 464, 589. 
in the case of a lease violation, including the power to terminate the lease. Where either party has termination authority, BIA approval for termination is not necessary. ${ }^{82}$

For individually-owned Indian land, negotiated remedies are available to the parties as long as the lease also specifies how those remedies are exercised by or on behalf of the Indian landowners of the applicable percentage of interests set forth in $\S 162.012$. But if the lease gives the parties the power to terminate the lease, BIA concurrence with termination is still required to ensure the consent of Indian landowners with the requisite percentage of interests. ${ }^{83}$ The regulations give leasing parties latitude in determining whether lease violations will be addressed by the tribe, and whether disputes will be resolved by a tribal court (or tribal governing body in the absence of a tribal court), other court of competent jurisdiction, or through alternative dispute resolution. ${ }^{84}$ While the BIA may not be bound by any resolutions reached in those forums, the BIA can defer to those proceedings before taking any action on alleged lease violations. ${ }^{85}$

In the absence of proceedings initiated by the parties to address a violation, or if the BIA finds that it should not defer to those proceedings, the BIA can issue a notice of violation to a lessee. For violations other than payment-related issues, the notice will give the lessee 10 days to cure, dispute, or seek additional time to cure the violation. ${ }^{86}$ For failure to pay violations, lessees will be required to provide proof of payment. ${ }^{87}$ Further, lessees and their sureties will continue to be responsible for obligations under the lease until the lease expires, or is terminated or cancelled.

If a violation is not cured or proof of payment is not provided as required by the notice of violation, BIA will consult with the landowner(s) and determine whether to cancel the lease, invoke other available remedies, allow the landowner(s) to invoke remedies available to them, or grant the lessee additional time to cure the violation. ${ }^{88}$ If a lessee remains in possession of the land after the expiration, termination, or cancellation of a lease, BIA may treat that possession as trespass. Absent notification from the requisite number of landowners under $\S 162.012$ that they are engaged in good faith negotiations with a holdover lessee for a new lease, BIA may attempt to recover possession of the property on behalf of the Indian landowners and pursue any other available remedies. ${ }^{89}$

\section{Subpart G}

The other substantive addition to Part 162 is Subpart G (Records). This subpart describes who owns records associated with Part 162, how such records must be preserved, and how the

\footnotetext{
${ }^{82}$ See id. §§ 162.365(a), 465(a), 590(a).

${ }^{83}$ See id. §§ 162.365(b), 465(b), 590(b).

${ }^{84}$ See id. §§ 162.365(e), 465(e), 590(e).

${ }^{85}$ See id.

${ }^{86}$ See id. §§ 162.366(b), 466(b), 591(b).

${ }^{87}$ See id. §§ 162.366(c), 466(c), 591(c).

${ }^{88}$ See id. $\S \S 162.367,467,592$. Following consultation, the BIA may seek to recover unpaid compensation and/or cancel the lease. See id. §§ 162.367(c), 467(c), 592(c). A decision to cancellation is subject to appeal under 25 C.F.R. Part 2. The BIA also reserves its right to invoke any other available remedies under the lease, and notes that Indian landowners can pursue available remedies under tribal law.

${ }^{89}$ See 25 C.F.R. §§ 162.371, 471, 596
} 
Paperwork Reduction Act affects Part 162. This subpart defines which records are the property of the United States if made or received by a tribe or tribal organization conducting a trust function under the Indian Self-Determination and Education Assistance Act (in other words, under a 638 contract or tribal self-governance compact) and the retention requirements associated with such records. ${ }^{90}$

\section{Rights-of-Way - 25 C.F.R. Part 169}

In late 2015, BIA published a final rule to comprehensively update the process for obtaining rights-of-way across Indian land set forth in 25 C.F.R. Part 169. The revised regulations became effective in April 2016. As with the goals for revising the leasing regulations, BIA expressly sought to support tribal self-determination and self-governance in updating Part 169, and generally mirrored the reforms implemented in the revisions to the Part 162. ${ }^{91}$ Notable additions to the right-of-way regulations not included in the leasing regulations are certain provisions more relevant to rights-of-way, such as a Strate fix, a prohibition of "piggy-backing" and more fulsome recognition of tribal sovereign authority. For example, unlike in the leasing context, a tribe can exercise an absolute veto of any right-of-way over land in which it owns a fractional interest, even if that interest is small. Part 169 includes six subparts: Purpose, Definitions, General Provisions (Subpart A); Service Line Agreements (Subpart B); Obtaining a Right-ofWay (Subpart C); Duration, Renewals, Amendments, Assignments, Mortgages (Subpart D); Effectiveness (Subpart E); and Compliance and Enforcement (Subpart F).

\section{Relevant Statutory Authority}

As with leasing, the federal authority to approve rights-of-way across federal Indian land has developed over time in numerous different statutes, creating significant complication. To mitigate complexity for granting new rights-of-way, the Part 169 revisions eliminate Interior's reliance on various right-of-way statutes that preceded the 1948 Indian Right-of-Way Act, ${ }^{92}$ and instead adopt an approach that provides a uniform system for rights-of-way resting on a single statutory authority. In relying on the IRWA, the BIA identified the purpose of allowing Indian landowners as much flexibility and control as possible over rights-of-way on their land. ${ }^{93}$

IRWA $\S 323$ grants the Secretary of the Interior broad, general authority to authorize rights-ofway across trust and restricted fee land held for individual Indians and tribes. ${ }^{94}$ Section 324 requires tribal consent for rights-of-way across tribal land. ${ }^{95}$ For land that is held for individual

${ }^{90}$ See id. §§ 162.701-702.

${ }^{91}$ See 80 Fed. Reg. at 72492.

${ }^{92}$ See 25 U.S.C. §§ 323-328 (“IRWA”).

${ }^{93} \mathrm{Id}$.

${ }^{94}$ As reflected in Part 169, the Secretary's approval authority has been delegated through the Office of Assistant Secretary - Indian Affairs to BIA Superintendents. See 25 C.F.R. § 169.304.

${ }_{95}$ More specifically, 25 U.S.C. § 324 refers to tribes organized under the Indian Reorganization Act of 1934 ("IRA"), see 25 U.S.C. §§ 5101-5129 ( including Alaska-related amendments enacted in 1936, id. § 5119), and the Oklahoma Indian Welfare Act, see id. §§ 5201- 5209 (“OIWA”). In proposing revisions to Part 169, Interior was 
Indians, however, consent for any particular individual landowner is not necessary if (1) the land is owned by more than one person, and the owner(s) of the majority of interests in the land consent to the grant (even if the whereabouts of some owners are unknown); (2) the heirs or devisees of a deceased owner of the land have not been determined, and the Secretary determines that a grant will not harm the land or any owner; or (3) the landowners are so numerous that the Secretary determines that obtaining consent would be impracticable, and that the grant would not substantially harm the land or any owner. Section 325 requires that the Secretary make a finding that compensation for any right-of-way across Indian land is just. ${ }^{96}$

\section{Part 169’s Revised Subparts}

\section{Subpart A}

Part 169, Subpart A sets out the purpose, definitions, and general provisions for the BIA's authorization of right-of-way regulations. Key provisions from this subpart identify the purposes for which rights-of-way can be obtained, who must obtain rights-of-way, and applicable law, jurisdiction, and taxation for rights-of-way grants under Part 169.

The regulations contemplate a broad range of right-of-way uses, including but not limited to railroads, public roads, public and community water lines, water control and use projects, oil and gas pipelines, electric transmission and distribution systems, telecommunications and broadband lines. ${ }^{97}$ Much like the Part 162 leasing regulations, Part 169 applies to both "Indian land" (which includes both "tribal land” and "individually-owned Indian land”) ${ }^{98}$ as well as "BIA land."99

criticized for applying the tribal consent requirement to all federally-recognized tribes although IRWA only expressly references a subset of all tribes. However, Interior's decision is consistent with the broad authority that Congress delegated under IRWA, which empowers the Secretary to grant rights-of-way "subject to such conditions as he may prescribe ..., " id. § 323, and achieves an important policy goal of putting tribes on equal footing except where Congress requires otherwise. Further, the application of the consent requirement for all tribes is consistent with the earliest versions of Interior's regulations implementing IRWA. See 16 Fed. Reg. at 8578 (Aug. 25, 1951); 33 Fed. Reg. 19803-19805 (Dec. 27, 1968) (rejecting a proposed change to eliminate the consent requirement for tribes not recognized under the IRA or OIWA).

${ }^{96}$ Sections 326-328 are less critical to this analysis. Section 326 clarifies that the general authority granted in 26 U.S.C. § 323 does not change the authority to authorize rights-of-way across Indian land provided in the Federal Power Act, 16 U.S.C. §§ 791a - 825r, or any other statute. Section 327 instructs that rights-of-way to be used by the United States may be granted under $\S \S 323-328$ through application of the agency with jurisdiction over the activity for which the right-of-way will be used. Finally, 25 U.S.C. § 328 authorizes the Secretary to promulgate rights-ofway regulations.

${ }^{97}$ See 25 C.F.R. \& 169.5(a). The BIA even anticipates applying Part 169 to other new right-of-way uses that were not foreseeable when the regulations were enacted. Id.

98 "Tribal land" is defined as "any tract in which the surface estate, or an undivided interest in the surface estate, is owned by one or more tribes in trust or restricted status.” Id. § 169.2. It also includes the surface estate of tribal trust lands reserved for BIA administrative purposes, as well as trust land held for IRA section 17 corporations. "Individually-owned Indian land" is "any tract in which the surface estate, or an undivided interest in the surface estate, is owned by one or more individual Indians in trust or restricted status." Id.

99 "BIA land" is "any tract, or interest therein, in which the surface estate is owned and administered by the BIA, not including Indian land.” Id. § 169.2. The Part 162 counterpart is "government land.” Part 169 expressly disclaims application to rights-of-way across fee land, including that the BIA will not condition a right-of-grant under Part 169 on an applicant having obtained a right-of way from the owners of any fee interest in land that could be subject to a 
A right-of-way may be granted by BIA only if an applicant first obtains the consent of the owner(s) of a majority interest in the land over which the right-of-way is sought. This requirement applies whether the applicant: owns no interest in the land; is an individual Indian landowner who owns a fractional interest in the land; or is a tribe or tribally-owned entity who owns a fractional interest in the land. ${ }^{100}$ Importantly, to the extent a tribe owns any fractional interest (regardless of size) in the land over which a right-of-way may be granted, the revised regulations clarify that the applicant must obtain the consent of the tribe. ${ }^{101}$

On issues of applicable law, jurisdiction, and taxation, the Part 169 revisions closely follow Interior's approach on the Part 162 revisions. As to applicable law, the Part 169 regulations provide that rights-of-way are subject to all applicable federal laws as well as tribal law, other than those tribal laws that are inconsistent with applicable federal law, and are generally not subject to state or local law. ${ }^{102}$ Addressing tribal jurisdiction, the regulations provide that a rightof-way is a non-possessory interest in land and title to the land does not pass to the grantee. The regulations also require that any right-of-way grant clarify that it does not diminish: tribal jurisdiction over the land subject to or any person or activity within the right-of-way; the tribe's power to tax the land, any improvements on the land or any person or activity within the right-ofway; the tribe's authority to enforce tribal law on land subject to and within the right-of-way; the tribe's inherent authority to exercise civil jurisdiction over non-Indians on Indian land; or the character of the land subject to the right-of-way as Indian country under 18 U.S.C. $§ 1151 .{ }^{103}$

On taxation, the regulations provide that subject to applicable federal law, permanent improvements in a right-of-way, regardless of ownership, are not subject to any tax or other fee imposed by a state or local government. ${ }^{104}$ Likewise, the regulations declare that neither the right-of-way interest itself, nor any activities conducted under a right-of-way, are subject to any tax or other fee imposed by a state or local government. ${ }^{105}$ The regulations, however, recognize that improvements, activities, and rights-of-way interest may be subject to taxation by the tribe with jurisdiction over the land. ${ }^{106}$

Subpart A finishes with provisions concerning how BIA provides notice to the parties to a rightof-way grant, how aggrieved parties may appeal BIA decisions made under Part 169, and how the Paperwork Reduction Act impacts Part 169. ${ }^{107}$

Part 169 right-of-way. Nor will the BIA include a fee interest in a tract in determining whether the sufficient percentage of interest required for consent has been reached. See id. § 169.3.

${ }^{100}$ See id. § 169.4 .

101 See id.

102 See id. § 169.9.

103 See id. § 169.10

104 See id. § 169.11(a) (1).

105 See id. § 169.11(a) (2).

106 See id. $\S$ 169.11(b). These provisions mirror the taxation provisions in the leasing regulations, 25 C.F.R. $\S$ 162.017, and rest on a similar preemption analysis. See 80 Fed. Reg. at 72505-72507.

107 See 25 C.F.R. $\S \S 169.12-14$. 


\section{Subpart B}

Subpart B covers the application of Part 169 to service lines, which are utility lines running from a main line, transmission line or distribution line established to supply a utility service (e.g., telephone, water, electricity, internet service) to a house, business or other structure. ${ }^{108}$ The purpose here was to reduce the regulatory burden of service line agreements to facilitate the development of utility services on Indian lands and reduce the costs to utilities and Indian people of connecting rural areas to utilities. These provisions create something of a safe harbor for service line agreements. While no BIA approval is required before service line agreements take effect, right-of-way grantees who want to establish service lines on Indian land must file service line agreements with BIA and such agreements must meet the requirements of Subpart B.

BIA recommends that such agreements include provisions addressing the mitigation of any damages incurred during construction, as well as restoration or reclamation of the premises upon agreement termination. ${ }^{109}$ As to consent required for a service line agreement, the regulations instruct that for tribal land, the utility provider and the tribe must execute a service line agreement before the utility provider may begin any work to construct service lines across tribal land. ${ }^{110}$ For individually-owned Indian land, the utility provider and the owners (or the legally authorized occupants of the land) must execute a service line agreement. Unlike leases and rights-of-way, BIA does not require a valuation for service line agreements. ${ }^{111}$ Executed service line agreements must be filed with BIA within 30 days of execution. ${ }^{112}$

\section{Subpart C}

The heart of Part 169 lies in Subpart C, which provides instruction for obtaining rights-of-way across Indian land, including needed application details, consent requirements, and BIA's process for granting rights-of-way.

A right-of-way application must identify: the land to be affected; the general location, purpose, and duration of the right-of-way; and the ownership of permanent improvements associated with the right-of-way, including who is responsible for building, operating, and managing the improvements. Applicants must also provide a legal description of the right-of-way and its boundaries; the applicable bond(s), insurance or other security required by the regulations; proof of notice of the right-of-way to all Indian landowners; proof of consent from Indian landowners that meets the rule's threshold levels, or a request for approval without landowner consent; valuation of the right-of-way (if necessary); and environmental and archaeological assessments need to comply with applicable federal and tribal environmental and land use requirements. ${ }^{113}$

\footnotetext{
108 See id. § 169.51.

109 See id. § 169.53.

110 See id. $\S 169.54(a)$ (this provision notes the required tribal consent may be delegated to the legally authorized occupants of the tribal land).

111 See id. § 169.55.

112 See id. § 169.56.

113 See id. § 169.102.
} 
For the access that may be needed to survey tribal or individually-owned Indian land or prepare other information required for an application, the regulations no longer require permission from the BIA. Rather, applicants must obtain permission from the Indian landowners. ${ }^{114}$ For grants across individually-owned Indian land, however, the BIA may still grant permission to access the land. ${ }^{115}$ Access through BIA permission may be particularly useful for fractionated tracts where some portion of the tracts owners object to the grant.

The rule's bonding provision mandates that an application for a right-of-way include: payment of bonds, insurance, or other security that cover the highest annual rental specified in the grant; estimated damages from construction of any permanent improvements; estimated damages and remediation costs from any potential release of hazardous material or waste that could harm the property; operation and maintenance changes for any land located within an irrigation project; and the restoration of the premises to their condition at the start of the right-of-way or some other condition agreed to by the landowners. ${ }^{116}$ The bonding requirement, however, may be waived by the BIA. For individually-owned Indian land, the BIA will consider waiver if either the grantee is a utility cooperative or tribal utility providing a direct benefit to the land, or if the landowners of a majority of the interests in the land request a waiver and the BIA decides such action is in the landowners' best interest. For tribal land, the BIA will defer to the maximum extent possible to a tribe's determination that waiver of the security requirement is in the tribe's best interest. ${ }^{117}$

Part 169's consent requirements are similar, but not identical, to those found in Part 162. For a right-of-way across tribal land, the applicant must obtain tribal consent. That tribal consent may impose restrictions or conditions, and the regulations acknowledge that such restrictions or conditions are automatically incorporated into the BIA's grant. ${ }^{118}$ For individually-owned Indian land, the grantee needs the consent of the owners of the majority of the interests in each tract affected by the grant. ${ }^{119}$ The BIA may, however, grant a right-of-way without the consent of any individual Indian landowners upon several conditions: (1) there are 50 or more co-owners of undivided trust or restricted interests in the property; (2) the BIA determines the grant will not cause substantial injury to the land or any landowner after looking at factors such as the term of the grant, the acres involved in the grant, the disturbance to the land, the activity to be conducted

\footnotetext{
${ }^{114}$ See id. § 169.101.

${ }^{115}$ See id. § 169.101(c).

116 See id. §169.103(a). The security requirement provisions further detail the form and adjustment of, and supporting documents for any security, along with requirements around cancellation, substitution, and the release process for the security. See id. §§ 169.103-104.

${ }^{117}$ In the event permanent improvements will be constructed, Subpart $\mathrm{C}$ also includes a due diligence requirement that obligates a grantee to complete construction within the schedule specified by the rights-of-way. A grantee's failure to adhere to the schedule or to sufficiently assure the BIA that construction will be completed in a timely manner could lead to termination of the right-of-way. Like the security requirement, the BIA retains discretion to waive this requirement upon finding that it is in the best interest of the Indian landowners. See id. § 169.105.

${ }^{118}$ See id. § 169.107(a).

119 See id. § 169.107(b). The regulations also authorize consent to be provided on behalf of individual Indian landowners who lack legal capacity to do so by adults with legal custody, guardians and other fiduciaries, anyone authorized by Interior regulations found at 43 C.F.R. § 1.3(b), a person or entity with power-of-attorney, or the BIA (under the circumstances described in Part 169). See 25 C.F.R. § 169.108(b).
} 
under the grant, potential environmental and safety impacts, and any landowner objections; (3) the BIA determines all landowners will be adequately compensated for the grant; and (4) notice of the grant is given to all landowners at least 60 days before the date of the grant, and the landowners are given 30 days to object. ${ }^{120}$ Like Part 162, a tract of land subject to Part 169 may qualify as both tribal land and individually-owned Indian land as long as both a tribe and individual Indians own trust or restricted fee interests in the tract. However, unlike leasing under Part 162, no right-of-way can be granted across a tract in which a tribe owns any interest, no matter how small, unless the tribe provides consent. ${ }^{121}$ Revised Part 169 also now requires that when there is a life estate on a tract that a right-of-way will cross, the grantee must have consent of both the life tenant and the owners of the majority of the remainder interest known at the time of grant application is submitted to the BIA. ${ }^{122}$

Compensation in the revised Part 169 also works much like Part 162. Whether tribal land or individually-owned Indian land, the BIA generally requires payment of not less than fair market value to Indian landowners for a right-of-way unless certain conditions are met. For a right-ofway over tribal land, the BIA will defer to the payment amount negotiated by the tribe and will not require a valuation of the right-of-way if the tribe, in writing, informs the BIA that the compensation is satisfactory; waives the valuation; and finds that the negotiated payment amount and waiver are in its best interest. Even if the BIA conducts a valuation at the tribe's request and provides the tribe with a fair market value, the BIA will defer to the tribe's decision to allow for the compensation negotiated by the tribe. If neither of these conditions are met, however, the BIA will require a grantee to pay the tribe fair market value for the right-of-way. ${ }^{123}$

For a right-of-way across individually-owned Indian land, an amount less than fair market value can suffice when the grantee is a utility cooperative providing a direct benefit to the land, or is a tribal utility, or if the individual Indian landowners waive in writing their right to receive fair market value and the BIA determines that waiver to be in the landowners' best interest. ${ }^{124}$ In the event the BIA grants a right-of-way without the consent of 100 percent of the landowners who own an interest in the tract, those landowners who did not provide consent are entitled to fair market value payment, unless the BIA determines that a smaller amount is adequate to compensate landowners. ${ }^{125}$

\footnotetext{
${ }^{120}$ See 25 C.F.R. § 169.107(b).

${ }^{121}$ See id. § 162.012 (setting forth the consent requirements for leases and noting that a non-consenting tribe will not be bound by a lease except with respect to the tribally owned fractional interest and will not be treated as a party to the lease).

122 See id. § 169.109.

${ }^{123}$ See id. § 169.110.

${ }^{124}$ See id. § 169.112 (the BIA will use factors such as the relationship between the grantee and the landowners and the existence of any special circumstances that would warrant approval of the grant).

${ }^{125}$ See id. § 169.112(d) (in requiring less than fair market value, the BIA will consider whether the grantee is a utility cooperative providing a direct benefit to the land, the grantee is a tribal utility, or the tribe or grantee will construct improvements benefitting the Indian landowners and it is in the best interest of all landowners to waiver the fair market value requirement).
} 
As to compensation reviews and adjustments, the regulations provide that no periodic review of compensation adequacy or adjustment is needed or required in the case of tribal land unless the tribe negotiates for review or adjustment. For individually-owned Indian land, compensation adequacy must be reviewed at least every fifth year unless payment is a one-time lump sum, the right-of-way term is five years or less, the grant provides for automatic adjustments, or the BIA determines that it is in the best interest of the Indian landowners not to require review or automatic adjustment after reviewing various factors. Unless the terms of the right-of-way provide otherwise, an adjustment will not go into effect unless the same consent requirements are met that apply to initial right-of-way grants. ${ }^{126}$

Other key compensation-related provisions cover how the BIA will determine fair market value and types of compensation. For a fair market value determination, the BIA may prepare a market analysis or other appropriate valuation method, or approve an analysis provided by the Indian landowners or the grantee. Such an analysis will meet the Part 169 requirements only if it is consistent with either the Uniform Standards of Professional Appraisal Practice, a valuation method that has been developed under 25 U.S.C. § 2214 and complies with DOI policy, or has been prepared by another federal agency. ${ }^{127}$

The regulations also build-in flexibility for how right-of-way payments are made. Grantees are authorized to make payments directly to tribes, as well as individuals, when there are ten or fewer landowners. ${ }^{128}$ Right-of-way grants may also provide for alternative forms of compensation, including in-kind consideration and payments based on percentage of income, as well as varying types of compensation, including different types of payments at specific stages during the life of the grant. Like other terms that may be negotiated in a right-of-way grant, the BIA will defer to a tribe's determination that alternative or varying compensation is in its best interest. For individually-owned Indian land, the BIA may approve a grant that provides for alternative or varying compensation if the agency determines that such an arrangement is in the landowners' best interest. ${ }^{129}$ Before granting a right-of-way across Indian land, the BIA must determine that the right-of-way is in the best interest of the Indian landowner. In undertaking that analysis, the BIA will consider potential environmental and adverse impacts, and may require modifications or mitigation measures to satisfy applicable legal requirements. ${ }^{130}$

Like the leasing regulations, the Part 169 revisions impose strict time limitations on BIA review. When a completed right-of-way application has been submitted, the BIA has 60 days to grant or deny the right-of-way, ask the applicant for revisions, or communicate that additional review time is needed. ${ }^{131}$ If the BIA does not meet applicable deadlines for acting on a right-of-way

\footnotetext{
${ }^{126}$ See id. § 169.113.

127 See id. § 169.114.

128 See id. § 169.116.

${ }^{129}$ See id. § 169.118.

${ }^{130}$ See id. § 169.123.

${ }^{131}$ See id. If the BIA requires additional time for review, it must identify its initial concerns and offer the applicant an opportunity to respond to those concerns within 15 days. Further, the BIA must issue a grant or denial of the application within 30 days of informing the applicant that additional review time is needed. See id.
} 
application, an appeals process is available to compel action on the application by petitioning a BIA Regional Director, the BIA Director, and ultimately the Interior Board of Indian Appeals. ${ }^{132}$ As with Part 162, the right-of-way regulations default in favor of granting an application submitted for approval. The BIA states that it will grant a right-of-way unless the applicable regulatory requirements under Part 169 have not been met or the BIA determines that there is a compelling reason to withhold the grant to protect the best interest of Indian landowners. ${ }^{133}$

Subpart C also provides important guidance on what information a right-of-way grant document must contain. Such details include the conditions or restrictions provided in the landowners' consents, what activity the grant authorized, whether assignment or mortgage of the right-of-way is permitted, and ownership of improvements constructed on the right-of-way. ${ }^{134}$ Along with conditions about grantee activity on the right-of way, access to landowner resources, and compliance with applicable law, among other provisions, Part 169 mandates that the grant include an express reservation of tribal jurisdiction over the land, activities and people within the right-of-way. ${ }^{135}$

Subpart C ends with instructions on a mix of right-of-way implementation issues. Key changes here include authorizing grants to include a provision, consistent with tribal law, which requires a grantee to give employment preference to tribal members, ${ }^{136}$ and eliminating "piggybacking” by requiring grantees to seek a new right-of-way grant if a proposed use is not within the same scope of an existing grant. ${ }^{137}$ In other words, a right-of-way that was granted for an electric utility line will not support a different purpose, such as a pipeline or sewage line, absent negotiation and consent of the landowners.

\section{Subpart D}

Subpart D covers right-of-way duration, renewals, amendments, assignments, and mortgages.

As to duration, the regulations provide that for tribal land, the BIA will defer to the tribe's determination that the term is reasonable. For individually-owned land, the BIA retains discretion to determine what duration is reasonable given the purpose of the right-of-way. Twenty years (including initial term and any renewal) is presumed to be a reasonable maximum duration for oil and gas purposes, while fifty years (including initial term and renewal) is the presumed maximum for all other purposes. Still, the BIA is willing to consider alternative durations for approval upon finding it would benefit Indian landowners, another Federal agency requires something different, or a tribe has negotiated a different duration and the right-of-way crosses tribal land. ${ }^{138}$

\footnotetext{
132 See id. § 169.123(c) (citing § 169.304).

133 See id. § 169.124.

134 See id. § 169.125(a).

135 See id. § 169.125(c).

136 See id. § 169.126.

137 See id. § 169.127.

138 See id. § 169.201.
} 
The BIA will approve renewal requests (defined by the BIA as extension of the term of an existing right-of-way without any other changes) as long as the initial term and renewal terms do not exceed what the BIA finds to be a reasonable duration; the right-of-way grant provides for renewal and specifies how compensation is to be determined in that circumstance; the grantee provides an affidavit confirming no change in the right-of-way; the initial term has not yet expired; there is no uncured violation of the right-of-way or the Part 169 regulations; and the landowner has provided consent. ${ }^{139}$ If, however, a proposed renewal involves any change to the original grant or the grant was silent concerning renewals, the BIA will treat the renewal request as a new right-of-way request. ${ }^{140}$

The revised regulations handle amendment, assignment and mortgage requests much like new grant applications. Upon receiving an executed amendment, assignment or mortgage, along with any other required submissions (such as proof of required consents, NEPA compliance documents, corrected legal descriptions), the BIA gets 30 days to act on the application. ${ }^{141}$ Further, the BIA will disapprove proposed amendments, assignments, and mortgages only in limited circumstances, such as when approved consents have not been obtained, the grantee is in violation of the right-of-way, sureties have not consented or sufficient insurance is not in place, the requirements of Subpart D are not met, or if the BIA finds a compelling reason necessary to protect the best interests of Indian landowners. ${ }^{142}$ Yet in all those situations, the BIA cannot unreasonably withhold approval, and must defer, to the maximum extent possible, to the Indian landowners' decision that the approval is in their best interests. ${ }^{143}$

Importantly, Subpart D also covers assignments and recordation. While assignments frequently are possible, they have not generally been recorded. As a result, the federal trustee has not, as a practical matter, known the identity of the owner of a right-of-way. Since it is the responsibility of the federal trustee to address trespass, the trustee must know who owns the right-of-way to be able to perform its responsibilities. Accordingly, §169.207 adopts a recordation requirement that simply ensures Interior has documentation of the assignee's right to occupy Indian land. The final rule asked assignees to record their interests with the relevant BIA land title records office.

\section{Subparts $\mathbf{E}$ and $\mathbf{F}$}

Part 169 ends with Subpart E (Effectiveness) and Subpart F (Compliance and Enforcement). Central to Subpart E is $\S 169.304$, which imposes a 15-day deadline on BIA Regional Directors

\footnotetext{
${ }^{139}$ See id. § 169.202.

140 See id.

${ }^{141}$ See id. §§ 169.205, 208, 211. In the event the BIA does not meet the prescribed deadlines for taking action on such requests (including the applicable deadline after exercising the option to take additional time for review of a proposed right-of-way amendment), the regulations provide a process to compel a decision through appeals to the a BIA Regional Director, the BIA Director, and ultimately, the Interior Board Indian Appeals. See id. Should the BIA deny an amendment, assignment, or mortgage request, that decision may be appealed under 25 C.F.R. Part 2. See id. $\S 169.303$.

${ }^{142}$ See id. §§ 169.206, 209, 212 (describing particular grounds on which an amendment, assignment or mortgage may be denied).

${ }^{143}$ See id.
} 
and the BIA Director to act on a notice to compel action when a BIA deciding official fails meet a deadline for acting on a request for a right-of-way, renewal, amendment, assignment or mortgage. This section also provides a right of appeal for inaction to the Interior Board of Indian Appeals. Further, Subpart E includes directions for appealing adverse decisions on right-of-way requests pursuant to 25 C.F.R. Part 2. ${ }^{144}$

Subpart F covers the procedures used to address compliance and enforcement for rights-of-way. These procedures are triggered upon occurrence of an abandonment, non-use, or violation of a right-of-way grant (including trespass, unauthorized construction, and late or insufficient payment). Subpart F authorizes the BIA or a tribe with jurisdiction, consistent with tribal law, to investigate compliance with a right-of-way grant. ${ }^{145}$ For grants across tribal land, the regulations provide that the tribe and the grantee may negotiate remedies for a violation, abandonment, or non-use of a right-of-way, which can include the power to terminate the right-of-way. Those remedies must be included in the tribe's consent to the grant at the time the BIA approval for the right-of-way is sought. If the negotiated remedies authorize one or both parties to terminate the right-of-way, additional BIA approval is not required to terminate the right-of-way. ${ }^{146}$ For individually-owned Indian land, the grantee and Indian landowners may negotiate remedies as long as the landowner consent documents explain how the remedies will be exercised. Where those negotiated remedies give one or both parties the authority to terminate the grant, BIA concurrence with the termination is nevertheless required to ensure that that the Indian landowners of the applicable percentage of interest have consented to the termination. ${ }^{147}$ The regulations give the parties flexibility to specify that negotiated remedies will apply in addition to or instead of the right-of-way cancellation remedy available to the BIA. Further, the grant can provide that violations will be addressed by a tribe and that disputes will be resolved by a tribal court (or governing body in absence of a court), another court of competent jurisdiction, or through other dispute resolution mechanisms. ${ }^{148}$

The BIA may take action on a violation of a right-of-way in the event negotiated remedies have not been triggered, or if it decides that deferring action is not appropriate. For grant violations other than payment-related issues, the BIA will give the grantee ten days to cure the violation, dispute that a violation has occurred, or request additional time to cure. ${ }^{149}$ For failure to pay, the BIA will issue notice of violation and require the grantee to provide proof of payment. When the grantee does not cure a violation, the BIA will consult with the landowners to determine whether cancellation, invoking other available remedies, or providing additional time to cure is appropriate. ${ }^{150}$ The regulations also provide that the BIA may invoke any other remedies available under the right-of-way grant, including collecting on any available bond, and that the

\footnotetext{
${ }^{144}$ See id. § 169.305.

145 See id. § 169.402.

${ }^{146}$ See id. § 169.403(a).

${ }^{147}$ See id. § 169.403(b).

${ }^{148}$ See id. § 169.403(d) - (e). Despite these options, the BIA reserves the right to not be bound by decisions made in any of these forums. See id.

${ }^{149}$ See id. § 169.404(b).

${ }^{150}$ See id. § 169.405(a).
} 
Indian landowners can pursue available remedies under tribal law. ${ }^{151}$ Note that the grantee remains responsible for the obligations to which it agreed under the grant until the grant expires or is terminated or cancelled, including any reclamation, restoration or other requirements that might survive the end of the grant. ${ }^{152}$

A right-of-way cancellation is not effective until 31 days after the grantee receives a cancellation letter from the BIA, or 41 days from the date the letter is mailed, whichever is earlier. However, the cancellation will not be effective if an appeal is timely filed unless it is made immediately effective under the appeals process set out under 25 C.F.R. Part 2. If not immediately effective, the cancellation decision does not alleviate the grantee's requirement to pay compensation and comply with the other terms of the grant. ${ }^{153}$

Other key provisions in Subpart F cover what happens when a grantee remains in possession of, or continues to occupy, a right-of-way after it has expired or has been terminated or cancelled. Assuming the grantee is not performing reclamation or other activities that it is obligated to carry out at the end of the grant, the BIA may treat possession as trespass under applicable law, and confer with the Indian landowners about how to proceed. Unless the parties are engaged in good faith negotiations for a renewal or a new right-of-way, the BIA may take action to recover possession for the landowners and pursue other available remedies, including forcible entry and detainer. ${ }^{154}$ Likewise, the BIA will treat as trespass any unauthorized use or possession of Indian land where a right-of-way would be required. In that event, BIA may take action to recover possession of the land and pursue any other available remedies. Further, Indian landowners may pursue available remedies, including remedies available under applicable tribal law. ${ }^{155}$

\section{Areas of Discord and Litigation}

As might be expected following significant revisions to regulations that govern use of Indian land for leasing and rights-of-way, particularly for commercial purposes, Interior's changes have been somewhat controversial. Many of the specific changes in the Parts 162 and 169 regulations are specifically designed to further tribal sovereignty. While that goal is not controversial when it is hypothetical, the Part 162 and 169 reforms have had real impacts when implemented. In litigation, opponents have targeted Interior's changes aimed at supporting the interests of tribal governments, including the revisions relating to taxation, jurisdiction and applicable law, and required consent. While those attacks have not yet succeeded, it seems likely that opponents will continue searching for vulnerabilities in the Part 162 and 169 revisions to reshape the current regulatory landscape.

\footnotetext{
${ }^{151}$ See id. $\S \S 169.405(\mathrm{c})$ - (d).

${ }^{152}$ See id. § 169.404(d).

${ }^{153}$ See id. § 169.409 .

154 See id. § 169.410 .

155 See id. § 169.413.
} 


\section{Applicable Taxes}

As discussed above, the Parts 162 and 169 changes add similar language on applicable taxes. Both parts indicate that "subject only to applicable law," no fee, tax, assessment, levy or other charge imposed by any state or local government are applicable to any permanent improvements located on leased land or in a right-of-way; activities conducted under an approved lease or under a right-of-way grant; or leasehold or possessory interest or right-of-way interest. ${ }^{156}$ Further, both parts acknowledge that improvements, activities, and leasehold or possessory interests and right-of-way interests may be subject to taxation by a tribe with jurisdiction. ${ }^{157}$

The legal effect of $\S 162.017$ (and thus, $\S 169.11$ given how similarly the sections are drafted) has been clarified by the courts. In Desert Water Agency v. U.S. Dept. of the Interior, ${ }^{158}$ the Desert Water Agency ("DWA"), a political subdivision of California, argued that in promulgating § 162.017, Interior may have been impermissibly attempting to preempt certain taxes and fees the DWA assesses against non-Indians who leased land under Part 162. DWA advanced two arguments in support of its claim: (1) § 162.017's reference to "applicable federal law" does not create any substantive change in the law, as the provision merely incorporates the U.S. Supreme Court's fact-specific balancing test announced in White Mountain Apache Tribe v. Bracker, and other existing federal law, to decide whether federal law preempts any particular state or local tax intended to apply to non-Indian conduct occurring on tribal land; or in the alternative, (2) to the extent $\S 162.017$ is intended to preempt DWA's charges, the provision is invalid as the BIA has no authority to issue a legislative rule that could have that legal effect.

DWA's district court challenge was dismissed for lack of standing. ${ }^{159}$ The district found that DWA had not suffered any injury due to the regulation as there was no allegation that any leaseholder refused to pay DWA's charges, that the BIA was planning any enforcement action against DWA, or that DWA was changing its behavior in response to $\S 162.017 .{ }^{160}$ On appeal, the Ninth Circuit determined that to examine whether DWA had standing in the case, the court must first determine the BIA's intended effect for § 162.017. In response to DWA's alternative argument that $\S 162.017$ was intended to displace the Bracker balancing test and preempt DWA's ability to charge leaseholder on tribal lands, Interior argued that $\S 162.017$ has no independent legal effect-it merely states publicly the BIA's view that under Bracker, courts must answer whether any specific state tax or charge is preempted on a case-by-case basis.

The Ninth Circuit agreed with Interior, finding that $\S 162.017$ does not attempt to change existing law, and thus does not operate to preempt DWA's charges. In reaching that conclusion, the Ninth Circuit pointed to the caveat at the beginning of each subsection of 162.017, "subject only to applicable Federal law" and noted Interior's description of that phrase as subsuming the

\footnotetext{
${ }^{156}$ See id. §§ 162.017(a) - (c); § 169.11(a).

${ }^{157}$ See id. §§ 162.017(a) - (c); § 169.11(b).

158849 F.3d 1250, 1252-1253 (9 $9^{\text {th }}$ Cir. 2017).

${ }^{159}$ See id. at 1258.

160 The district court also found that DWA's challenge was not ripe because the rule contained a grandfather clause. See id. at 1253.
} 
Bracker test. ${ }^{161}$ While the Ninth Circuit's analysis highlighted language in the final rule's preamble arguably supporting DWA's view that the BIA was attempting to preempt state and local taxes expressly under $\S 162.017,{ }^{162}$ the court was not swayed by that argument. The Ninth Circuit ultimately concluded, "the language of the regulation itself-as distinct from the preamble-is perfectly consistent with the agency's view that $\S 162.017$ leaves Bracker in place while merely setting forth the agency's interpretation of how Bracker should apply over the generality of cases, without operating to preempt any specific state law." 163 The Ninth Circuit also said "Interior's views as set out in 162.017 may well influence courts when they gauge the federal and tribal interests under Bracker," "[b]ut on the ultimate question of whether any specific state tax or charge is preempted under Bracker, ... courts must answer such questions in the same way they always have, by applying the Bracker text de novo.”164

In supporting its conclusion, the Ninth Circuit cited a 2015 Eleventh Circuit decision, Seminole Tribe of Fla. v. Stranburg ${ }^{165}$ in which the Seminole Tribe relied, in part, on § 162.017 to support a claim that the imposition of a state rental tax and utility tax on leased tribal land was preempted. Looking to 25 U.S.C. § $465^{166}$ and separately undertaking a Bracker analysis, the court agreed with the tribe that the rental tax was preempted. The court also determined that under Bracker, the utility tax was not preempted. In examining the effect of § 162.017, however, the court concluded that in the preamble to the Part 162 final rule, Interior had only outlined the Bracker test and applied it generally. Acknowledging that the "Preamble analysis and the actual statutes and regulations provide, in this case, substantial evidence of the extensive federal regulation of Indian land leasing to inform the Bracker balancing inquiry,” the Eleventh Circuit refused to defer to Interior's preemption analysis in the preamble, concluding that Interior had not examined Florida's interest in imposing the rental tax at issue. ${ }^{167}$ Thus, consistent with the position that Interior put forth in Desert Water Agency, neither § 162.017 nor § 169.11 are read to "displace or modify Bracker — or otherwise change existing law-and therefore [do not] operate to preempt any specific state tax."168

Use of the Part 162 regulations as part of a Bracker analysis has also been recently confirmed by a California federal district court. In Agua Caliente Band of Cahuilla Indians v. Riverside

\footnotetext{
${ }^{161} I d$. at $1254-55$.

162 See id. at 1255 ("the preamble states that '[t]he Federal statutes and regulations governing leasing on Indian lands ... occupy and preempt the field of Indian leasing. The Federal statutory scheme for Indian leasing is comprehensive, and accordingly precludes State taxation."') (quoting 77 Fed. Reg. at 72,447).

${ }^{163}$ Id. at 1255.

${ }^{164} \mathrm{Id}$. at 1254.

165799 F.3d 1324 (11 ${ }^{\text {th }}$ Cir. 2015).

${ }^{166}$ Editorially reclassified to 25 U.S.C. § 5108 (2017). In its § 465/§ 5108 analysis, the Eleventh Circuit affirmed the district court's decision, which relied heavily on the U.S. Supreme Court's decision in Mescalero Apache Tribe v. Jones, 411 U.S. 145 (1973) "for the proposition that § 465 prohibits taxes on land rights that are so connected to the land that the tax amounts to a tax on the land itself.” 799 F.3d. at 1329.

${ }^{167}$ Id. at $1338-1339$.

${ }^{168}$ Desert Water Agency, 849 F.3d at 1256.
} 
County, ${ }^{169}$ the federal district court for the Central District of California considered whether a possessory interest tax assessed by Riverside County, and imposed on non-Indian lessees who occupy trust land within the Agua Caliente reservation was preempted. Recognizing the Ninth Circuit's ruling in Desert Water Agency that $\S 162.017$ has no independent legal effect on a court's preemption analysis, the district court noted that "[t]he regulations that caution against state and local taxation of Indian lands (and the Secretary's interpretation thereof) align with the federal policy of promoting tribal self sufficiency.... Given the Ninth Circuit's pronouncements on the federal statutory and regulatory scheme of Indian leasing, the Secretary's thorough and persuasive interpretation of the statutes and regulations it administers, and the federal policy of promoting Indian welfare and economic independence, the Court concludes that the federal interests here. . . are pervasive enough to preclude the burdens of a tax absent sufficient state interest." ${ }^{" 170}$ Weighing federal interests and tribal interests against state interests as directed by Bracker, the court concluded that the Riverside County's possessory interest tax was not preempted. ${ }^{171}$

\section{The Part 169 Facial Challenge}

While concerns around the revised leasing regulations appear to have focused primarily on the effect of $\S 162.017$, the criticism of the revisions to the right-of-way regulations have been much broader, as questions have been raised about the legality of various provisions in the revised Part 169.

Those criticisms culminated in Western Energy Alliance v. U.S. Department of the Interior, ${ }^{172} \mathrm{a}$ facial challenge filed in March 2016 shortly before the revised Part 169 was to become effective. Plaintiff Western Energy Alliance sought to enjoin the Part 169 revisions from going into effect, raising four claims: (1) the final rule exceeds Interior's delegated authority under IRWA; (2) the final rule is contrary to federal law regarding jurisdiction, taxation, and property rights within federally granted rights-of-way on Indian land; (3) the final rule is arbitrary and capricious; and (4) the final rule violates the National Environmental Policy Act.

Summarizing the Plaintiff's challenge, the court stated, "Western Energy contends [Interior's and the BIA's] promulgation of the Final Rule exceeds the authority delegated by statute altering property rights, permitting surface owners to terminate rights-of-way without [Interior and BIA] involvement, and by permitting the BIA to impose trespass sanctions in the absence of statutory authority. Western Energy further contends the Final Rule is contrary to law because the rule

\footnotetext{
169 Order on Parties' Motions for Summary Judgment, Agua Caliente Band of Cahuilla Indians v. Riverside Cty., No. 5:14-cv-00007-DMG-DTB (C.D. Cal. Jun. 15, 2017)

${ }^{170}$ Id. at $22-23$.

${ }^{171}$ See id. at 31. In reaching this conclusion, the court rejected the argument that the challenged tax needed to fund specifically lease-related services to survive a Bracker analysis. The court found that while the tax revenues were not traced dollar for dollar to services that the defendants provided on the tribe's land, the defendants had adequately demonstrated a relationship between the possessory interest tax and the non-Indian use and enjoyment of the Indian lands. Further, the court stated that the state services provided on and around the tribe's reservation directly supported the lessee's enjoyment of the trust land. Id. at 27-28.

${ }^{172}$ No. 1:16-cv-050 (D.N.D. filed Mar. 11, 2016).
} 
alters property rights, expands tribal jurisdiction, authorizes tribal taxation of rights-of-way, and conflicts with well-established United States Supreme Court precedent.”173 Evaluating Western Energy's request under a preliminary injunction standard, the court noted the high bar the claims had to meet given that a facial challenge will fail if a rule is valid under any set of circumstances. $^{174}$

Rejecting Western Energy's claims, the court found that the revised Part 169 "does not contain any sweeping grant of tribal jurisdiction or taxation authority over rights-of-way." 175 Pointing out that $\S 169.9$ provides that rights-of-way are subject to federal law and that $\S 169.10$ authorizes tribal taxation subject to federal law, the court concluded that "[a]ny inquiry applying federal law in this context would be fact intensive and cannot be done in the abstract context of a facial challenge ... ."176 Likewise, the court rejected Western Energy’s concerns about negotiated remedies and right-of-way termination as provided in $\S 169.403$, finding that "it is entirely within the control of the grantor to decide whether to accept any of the negotiated remedy terms contemplated by Final Rule $\S 169.403$. Thus, there are clearly sets of circumstances that exist in which this provision or rule would be valid."177

On the question of irreparable harm, the court could not identify a concrete injury to Western Energy that was actual and imminent. Concerns about the legality of authority to terminate right of grants without the involvement of the United States were deemed too speculative. ${ }^{178}$ Further, the court held that claims that the revised Part 169 “will subject [Western Energy's] members to tribal jurisdiction or taxation are based on a litany of contingencies too numerous to contemplate. Such determinations are fact intensive, contingent on future events, and require the application of United States Supreme Court case law and other federal case law, rather than the simple citation of an administrative rule." 179

Despite rejecting Western Energy's request for a preliminary injunction, the court did not rule without criticizing Interior's revision efforts: "Suffice it to say the need for this new Final Rule is unclear at best, particularly when the long-established process for obtaining BIA grants of rightsof-way across tribal lands seems to have worked relatively well for more than 60 years. . . . Although the current regulations may arguably have been in need of some updates and

\footnotetext{
173 Order Denying Plaintiff's Motion for Preliminary Injunction, slip op. at 8-9, (D.N.D. April 19, 2016). Prior to the court's ruling, two other parties sought to intervene in the litigation: the Three Affiliated Tribes of the Fort Berthold Reservation, who supported the United States' position in the litigation, and maintains significant energy development activities on its lands; and the New Mexico Oil and Gas Association, who raised claims similar to those made by Western Energy Alliance. Both motions were denied as moot after Western Energy Alliance voluntarily dismissed the case.

174 See slip op. at 6 (citing Reno v. Flores, 507 U.S. 292, 301 (1993)).

${ }^{175} \mathrm{Id}$. at 10.

${ }^{176}$ Id.

${ }^{177} \mathrm{Id}$. at 11.

178 See id. at 12-13.

${ }^{179} \mathrm{Id}$. at 13.
} 
'modernization,' the Final Rule will likely create far more confusion, chaos, and litigation than what the Department of the Interior ever contemplated." 180

The Western Energy Alliance ultimately dismissed its action before the court reached the substantive merits of its claim, so the ultimate question on the merits was never finally decided by that court.

\section{Part 169's Consent Requirements}

Although not directly challenged in litigation, Part 169's revised consent requirements are relevant to recent litigation developments relating to expired rights-of-way and condemnation authority. As discussed above, $\S 169.107$ now requires tribal consent for any right-of-way crossing trust or restricted fee land in which a tribe has an ownership stake. ${ }^{181}$ This mandate reaches lands owned only by tribes as well as lands in which a tribe may own only a small undivided interest and a large majority of the interests are owned by individual Indians. As such, tribes have veto authority any time a proposed right-of-way would cross land in which they hold any ownership interest.

This approach appears consistent with the best reading of IRWA's consent requirement. Under 25 U.S.C. § 324, "[n]o grant of a right-of-way over and across any lands belonging to a tribe ... shall be made without the consent of the proper tribal officials." Concerning land owned by individual Indians, § 324 authorizes Interior to grant a right-of-way without the consent of an individual Indian landowner if, among other reasons, "the land is owned by more than one person, and the owners or owner of a majority of the interests therein consent to the grant." While a fractionated tract owned in part by a tribe and by individual Indians arguably can be described both as "lands belonging to a tribe" as well as "lands of individual Indians," § 324 only expressly authorizes a right-of-way without consent in the case of individual Indian land. The statute does not contemplate non-consensual authorization where tribal ownership exists.

Critics of Part 169's revised consent requirements may point to the Indian Land Consolidation Act ${ }^{182}$ as more relevant authority for deciding whether a tribe may veto a right-of-way grant over land in which the tribe owns only a minority interest. The argument has been made that under ILCA, where Congress expressly contemplated tribal ownership of fractionated interests alongside individual tribal members, the statute states an intention to treat tribal interests no different than individually-owned interest. For example, in authorizing the Secretary to approve leases, rights-of-way and other agreements for allotted lands, ILCA provides that such authority applies to "any undivided interest in allotted land held by the Secretary in trust for tribe ... even

\footnotetext{
${ }^{180} \mathrm{Id}$. at 15.

181 Section 169.2 defines "tribal land," in relevant part, as "any tract in which the surface estate, or an undivided interest in the surface estate is owned by one or more tribes in trust or restricted status.” (emphasis added).

182 See 25 U.S.C. 2201 et seq. (2008) (Indian Land Consolidation Act (“ILCA”)).
} 
though the Indian tribe did not consent to the lease or agreement.” ${ }^{183}$ Further, ILCA's legislative history suggests that neither Congress nor the Department of the Interior understood that tribally owned interests acquired under ILCA would be treated differently than interests owned by individual Indians. ${ }^{184}$

However, nothing in ILCA requires that its treatment of fractionated interests held by tribes and individual Indians be the exclusive way that Interior treats fractionated interests for the purposes of granting rights-of-way. Indeed, Interior's authority to approve leases, rights-of-way and other agreements on fractionated lands under ILCA is discretionary. ${ }^{185}$ Similarly, IRWA generally authorizes (but does not require) the Secretary to approve rights-of-way across any trust or restricted fee land held for tribes or individual Indians. ${ }^{186}$ While Congress has enacted multiple authorities under which rights-of-way could be issued across Indian land, Interior decided in revising Part 169 to "consolidate[] approval of all types of rights-of-way across Indian land under one set of regulations, implementing the general statutory authority at 25 U.S.C. 323328." "187 In rejecting the argument that Part 169's general tribal consent requirement is inconsistent with authority under ILCA, 25 U.S.C. § 2218, for approving rights-of-way without tribal consent where the tribe owns less than a majority interest, Interior stated, "[b]ecause the regulations rely primarily on 25 U.S.C. 323-328, and not 25 U.S.C. 2218 or other statutes authorizing the granting of rights-of-way, tribal consent is required for any tract in which a tribe owns an interest. . . . Requiring tribal consent restores a measure of tribal sovereignty over Indian lands and is consistent with principles of tribal self-governance that animate modern Federal Indian policy." 188

Interior's approach is underscored by the Tenth Circuit's recent decision in Public Service Company of New Mexico v. Barboan. ${ }^{189}$ In that case, a public utility company argued that it had

\footnotetext{
${ }^{183}$ Id. at 2218(d) (2) (A). While contemplating that tribal consent is not required for agreements affecting triballyowned allotted interests, ILCA also provides in $\S 2218$ (d) (2) (B) that "the lease or agreement described in subparagraph (A) shall apply to the portion of the undivided interest in allotted land described in such paragraph (including entitlement of the Indian tribe to payment under the lease or agreement), and the Indian tribe shall not be treated as a party to the lease or agreement. Nothing in this section (or the lease or agreement) shall be construed to affect the sovereignty of the Indian tribe."

${ }^{184}$ See S. Rept. No. 106-361, at 20 (2000) ("the provision of the ILCA that provides for majority approval of leases . . . will apply to interests held for the tribe by the Secretary"); id. at 32-33 (Nov. 3, 1999 Letter from Kevin Gover, Assistant Secretary for Indian Affairs to Ben Nighthorse Campbell, Chairman, U.S. Senate Committee on Indian Affairs); id. at 34 ("S.1586 would adopt a uniform standard for all leases, rights-of-way, sales of natural resources or similar transactions, regardless of the use to which the property will be put. It would authorize the Secretary to approve such a transaction if it is supported by the owners of a majority of the interests in a parcel of land.”).

${ }^{185}$ See 25 U.S.C. § 2218(a) (“the Secretary may approve any lease or agreement ...”) (emphasis added).

${ }^{186}$ See id. § 323 ("The Secretary . . . is empowered to grant rights-of-way for all purposes, subject to conditions as he many prescribe, over and across” any trust or restricted fee lands for individual Indians or tribes).

18780 Fed. Reg. at 72493.

${ }^{188}$ Id. at 72509.

189857 F.3d 1101 (10 ${ }^{\text {th }}$ Cir.2017) (petition for rehearing and rehearing en banc denied July 21, 2017). It is unclear at this time whether the appellant will seek review by the U.S. Supreme Court. The appellant indicated plans to do so in a motion to stay the mandate that the Tenth Circuit denied on July 31, 2017.
} 
a statutory right under 25 U.S.C. $\S 357^{190}$ to condemn a right-of-way on two fractionated trust parcels in New Mexico in which the Navajo Nation acquired undivided interests pursuant to ILCA. The court rejected the "once an allotment, always an allotment" approach offered by the utility company, which argued that allotted Indian land may be condemned under 25 U.S.C. $\S$ 357 regardless of the persons or entities who own fractionated interests in the land, or even if a tribe fully reacquires all of the interests in an allotted parcel. The court noted, "Congress has neither enacted nor amended $\S 357$ to establish that ever-allotted status would permanently trump any later tribal acquisitions. . . . Section 357 does not reach tribal lands, even if land reobtains that status long after it was allotted." 191

The Tenth Circuit relied upon the Eighth Circuit's decision in Nebraska Public Power District v. 100.95 Acres of Land in Thurston County, ${ }^{192}$ which encountered a request by a public utility company to condemn under $\S 357$ parcels of land in which the Winnebago Tribe owned undivided future interests. There, the court held that those future interests owned by the Winnebago Tribe were sufficient to make the parcels tribal land, and outside the scope of $\S 357$. In support of that position, the Eighth Circuit cited Interior's then-controlling 1948 Act regulations, which treated any tribal interest in a parcel as sufficient to give that parcel tribal land status, just as the current regulations do. ${ }^{193}$ Although the Tenth Circuit acknowledged that the Part 169 regulations had limited impact on its holding given that the regulations do not apply to condemnation actions, the court nevertheless viewed the regulations as amplifying its conclusion in light of $\S 357$ 's plain meaning. ${ }^{194}$ Ultimately, the Tenth Circuit concluded: “[w]e side with the Eighth Circuit and agree with the district court's conclusion: 'When all or part of a parcel of allotted land owned by one or more individuals is transferred to the United States in trust for a tribe; that land becomes "tribal land" not subject to condemnation under §357."”195 Consistent with the current definition of "tribal land" in 25 C.F.R. $\S$ 169.2, the Tenth Circuit recognized that the status of land changes once acquired by a tribe and highlighted Interior's view that "the different treatment afforded to individual and tribal interests befits the unique government-togovernment relationship between the United States and Native tribes, and federal attempts to promote tribal self-governance.”196

\footnotetext{
19025 U.S.C. § 357 provides, “[l]ands allotted in severalty to Indians may be condemned for any public purpose under the laws of the State or Territory where located in the same manner as land owned in fee may be condemned, and the money awarded as damages shall be paid to the allottee."

191 Barboan, 857 F.3d at 1109.

192719 F.2d 956 ( ${ }^{\text {th }}$ Cir. 1983).

${ }^{193}$ See Barboan, 857 F.3d at 1110 (citing 25 C.F.R. § 169.1(d) (1983)).

194857 F.3d at $1110-11$.

195 Id. at 1111.

${ }^{196}$ Id. (citing 80 Fed.Reg. at 72492). As an interesting side note, the Tenth Circuit gave additional instruction as to how condemnation and/or seeking a right-of-way would work in the case of fractionated parcels in which a tribe owns interest alongside individual Indians: "[b]ecause we hold that the tribal interests makes [the land at issue] tribal land for purposes of $\S 357$, PNM cannot proceed with a condemnation action against the individual interest in the parcels while leaving tribal interests undisturbed. Holding otherwise would accomplish little other than to waste judicial resources, and those of PNM, as PNM would still need tribal consent before it could obtain a right-of-way under 25 U.S.C. § 324.” Id., n.5.
} 


\section{Retroactivity}

As the Part 169 revisions were being developed, a number of commenters, particularly those representing industry interests, raised concerns about Interior's proposal to include language that would apply newly enacted provisions to existing rights-of-way that were approved under the pre-2016 version of Part 169. Opponents argued that such a provision would confuse and complicate the administration of existing rights-of-way, doing anything but achieving Interior's stated policy goal of clarifying and streamlining Interior's rights-of-way requirements. Opponents noted that most pre-existing grants are silent on terms that the new regulations impose, and that retroactive application of the revised Part 169's provisions to existing rights-ofway unlawfully alters bargained for contractual rights and expectations that have been set for grantees, Indian landowners, and Interior.

Despite these objections, the final rule states that for rights-of-way predating the effective date of the rule revisions, Part 169's new procedural provisions will apply unless they conflict with explicit provisions of the existing right-of-way or the statute authorizing the right-of-way grant. ${ }^{197}$ In expanding on the breadth of this requirement, the Part 169 preamble indicates that the procedural provisions "include procedures for obtaining amendments, assignments, mortgages, renewals, and complying with and enforcing rights-of-way grants. ... An example of a non-procedural provision is a regulatory statement of what jurisdiction applies." ${ }^{198}$ Possibly foreshadowing future disputes in this area, the preamble also notes that "[t]he question of whether tribal law or taxes apply to preexisting right-of-way grants after the effective date of the new regulations is not before the Department at this point, but to the extent any preexisting rightof-way is assigned or amended, the provisions of the new regulations govern."199

\footnotetext{
197 See 25 C.F.R. § 169.7

19880 Fed. Reg. at 72502.

${ }^{199}$ Id.
} 


\section{Conclusion}

The new Part 162 Leasing and Part 169 Right-of-Way regulations reflect improvements in the economic environment in Indian country. Each regime provides reduced unguided federal discretion, provides greater clarity, and provides certainty of a fast decision. Each will provide greater economic opportunities to tribes and individual Indian owners. Each also furthers tribal sovereignty, heightening the importance of careful cooperation with the relevant Indian tribe when economic opportunities are pursued on Indian lands. While the regulations serve the interests of tribal sovereignty, they empower landowners to strike their own deals and preserve significant flexibility among parties to construct a relationship that suits them around remedies and other issues. While litigation may well continue around a handful of the provisions of each regime, the bulk of the provisions are uncontroversial and will reflect marked improvements in the business environment on Indian lands. 